Working Paper/Document de travail 2015-5

\title{
Motivations for Capital Controls and Their Effectiveness
}

by Radhika Pandey, Gurnain K. Pasricha, Ila Patnaik and Ajay Shah 
Bank of Canada Working Paper 2015-5

February 2015

\title{
Motivations for Capital Controls and Their Effectiveness
}

by

\section{Radhika Pandey, ${ }^{1}$ Gurnain K. Pasricha, ${ }^{2}$ Ila Patnaik ${ }^{1}$ and Ajay Shah ${ }^{1}$}

\author{
1Macro/Finance Group \\ National Institute of Public Finance and Policy \\ New Delhi, India 110067 \\ radhesp@gmail.com \\ ilapatnaik@gmail.com \\ ajayshah@mayin.org \\ 2International Economic Analysis Department \\ Bank of Canada \\ Ottawa, Ontario, Canada K1A 0G9 \\ gpasricha@bankofcanada.ca
}

Bank of Canada working papers are theoretical or empirical works-in-progress on subjects in economics and finance. The views expressed in this paper are those of the authors.

No responsibility for them should be attributed to the National Institute of Public Finance and Policy or the Bank of Canada. 


\section{Acknowledgements}

We thank Vikram Bahure, Apoorva Gupta and Shekhar Hari Kumar for excellent research assistance. We also thank Rose Cunningham, Michael Ehrmann, Atish Ghosh, seminar participants at the Bank of Canada, European Central Bank, University of Southern California, Canadian Economic Association meetings and research meetings of the National Institute of Public Finance and Policy for useful comments. 


\begin{abstract}
We assess the motivations for changing capital controls and their effectiveness in India, a country with extensive and long-standing controls. We focus on the controls on foreign borrowing that can, in principle, be motivated by macroprudential concerns. We construct a fine-grained data set on capital control actions on foreign borrowing in India. Using event study methodology, we assess the factors that influence these capital control actions, the main factor being the exchange rate. Capital controls are tightened after appreciation, and eased after depreciation, of the exchange rate. Macroprudential concerns, measured by variables that capture systemic risk buildups, do not seem to be a factor shaping the use of capital controls. To assess the impact of controls, we use both event study and propensity score matching methodologies. Event study methodology suggests no impact of capital controls on most variables evaluated, but reveals limited evidence that capital controls relieve currency pressures in the short term. However, even this limited evidence disappears once selection bias is controlled for.
\end{abstract}

JEL classification: F32, G15, G18

Bank classification: International topics; Financial stability; Exchange rate regimes;

Financial system regulation and policies

\title{
Résumé
}

Les auteurs examinent les raisons pour lesquelles des changements sont apportés au régime de contrôle des mouvements de capitaux en Inde (pays où, de longue date, ces contrôles occupent une place importante), ainsi que l'efficacité de ces modifications. Plus spécifiquement, l'étude porte sur les restrictions touchant les emprunts à l'étranger qui peuvent, en principe, être motivées par des préoccupations d'ordre macroprudentiel. Les auteurs constituent pour ce faire un ensemble très complet de données. Au moyen de l'approche événementielle, ils étudient les facteurs qui influencent les modifications décidées par les autorités, le principal d'entre eux étant le taux de change. Le contrôle des mouvements de capitaux est resserré en cas d'appréciation de la monnaie et assoupli en cas de dépréciation. Les considérations macroprudentielles, évaluées à l'aide de variables rendant compte de l'intensification du risque systémique, ne semblent pas être un facteur déterminant en ce qui concerne la décision de resserrer ou d'assouplir les règles. Pour évaluer l'incidence du contrôle des capitaux, les auteurs emploient l'approche événementielle ainsi que des méthodes d'appariement par score de propension. La première approche donne à penser que le contrôle des capitaux n'a pas d'effet sur la plupart des variables à l'étude, mais qu'il pourrait atténuer les pressions exercées sur la monnaie à court terme. Cependant, une fois le biais de sélection pris en compte, même cette incidence ténue disparaît.

Classification JEL : F32, G15, G18

Classification de la Banque : Questions internationales; Stabilité financière; Régimes de taux de change; Réglementation et politiques relatives au système financier 


\section{Non-Technical Summary}

The volatility of capital flows during and after the global financial crisis has reopened the debate on the place of capital controls in the policy toolkit of emerging-market economies (EMEs). The international policy debate on capital controls stems from the fact that while restrictions on capital flows can potentially reduce volatile inflows in the country that is imposing them, these controls can have global implications, going beyond the economy in which they are imposed.

There are two main objectives that capital control policies could pursue. The first is exchange rate management. Capital controls have been held out as a mechanism for avoiding the excessive exchange rate appreciation associated with surges in net capital inflows. A second possible use of capital controls is as a tool for macroprudential policy, i.e., systemic risk mitigation. An extensive literature has shown that, for EMEs, excessive foreign currency borrowing can lead to future financial crashes, and capital controls can be used to limit this borrowing.

In this paper, we construct a precise vocabulary for classifying all capital control actions (CCAs) on foreign borrowing for India and compile a definitive database about these CCAs for the period from January 2004 to September 2013. Using this data set, we address two questions: (i) Under what circumstances do EME policy-makers use capital controls-when exchange rate pressures or systemic risk concerns are predominant? (ii) What impact do different capital controls have?

Our focus on India is guided by the literature, which has suggested that once a country achieves an open capital account, episodic introduction of controls is not useful. Hence, if capital controls are to be used as a tool for policy, this has to be done in the context of a comprehensive administrative system for capital controls, where the government has the ability to interfere in all cross-border transactions. India is one of only two major EMEs that have a comprehensive administrative system for capital controls (the other is China). We focus only on controls on foreign borrowing, since these could, in theory, be particularly useful as a tool for macroprudential policy.

Our results on the first question suggest that the main factor motivating changes in capital controls seems to have been the exchange rate. Capital controls were tightened after appreciations and eased after depreciations. Measures of systemic risk do not seem to be a factor shaping the use of capital controls.

We explore the impact of these actions using event studies. There is a strong selection process at work: CCAs are likely to take place under certain circumstances. We therefore draw on recent developments in propensity score matching to match the date on which a CCA was applied with a similar date with no CCA. This permits causal identification of the impact of the CCA. Our results show no impact of the CCAs in any dimension evaluated. We also analyze several sub-categories of controls to determine whether certain kinds of restrictions would be more effective than others, but find no effect in all subcategories studied. 


\section{Introduction}

The global financial crisis has re-opened the debate on the place of capital controls in the policy toolkit of emerging-market economies (EMEs). The volatility of capital flows during and after the global financial crisis, and the use of capital controls in major EMEs, particularly in Brazil, spawned a vigorous debate among policy-makers on the legitimacy and usefulness of capital controls. The international policy debate on capital controls stems from the fact that while restrictions on capital flows can potentially stem volatile inflows in the country that is imposing them, these controls can have global implications, going beyond the economy in which they are imposed. They can distort the global allocation of capital by diverting inflows to economies that allow freer movement of capital. They can also be used as a tool in a currency war, to reduce appreciation pressures. The International Monetary Fund (IMF) has shifted its position and now suggests that these controls are a legitimate tool, and may be imposed when a country faces a surge in net capital inflows, even after taking into account multilateral considerations (IMF, 2012).

What goals could capital controls pursue? The first dimension lies in macroeconomic policy. Capital controls have been held out as a mechanism for avoiding overheating of the economy and excessive exchange rate appreciation associated with surges in net capital inflows (Pradhan et al., 2011). Others have argued that while capital controls should not be used as a tool for macroeconomic policy, they can be useful for macroprudential policy, i.e., systemic risk mitigation. There are two oft-cited examples of cases where capital controls could be useful from a macroprudential perspective. First, when excessive foreign inflows risk creating domestic imbalances that cannot be directly addressed through domestic prudential regulation (for example, loan-to-value ratios or capital buffers at financial institutions), since the flows are not directly intermediated through the domestic financial system. In this case, proponents argue that controls on cross-border transactions may be useful (Ostry et al., 2012).

A second instance where, in theory, capital controls may be useful from a macroprudential perspective relates to foreign (and/or foreign currency) borrowing in EMEs. An extensive literature has shown that, for EMEs, excessive foreign currency borrowing can generate sub-optimal outcomes from a systemic risk perspective (Goldstein and Turner, 2004; Eichengreen et al., 2007). Given the evidence linking external debt, especially in foreign currencies, to financial fragility, capital controls (particularly on foreign borrowing) could, 
in theory, be justified as a tool for macroprudential management. Specifically, these controls could allow the authorities to influence the level of short-term foreign currency borrowing, high levels of which have been associated with past EME crises.

The IMF staff position (Ostry et al., 2010) is that capital controls can legitimately be used in the pursuit of both macroprudential and macroeconomic management, as measures of the last resort. While the IMF has held out this possibility, a lot remains to be done towards constructing a full strategy that would constitute the "best practices" for capital control regulations. The operation of a complex system of capital controls is like any other complex intervention by the government: it is vulnerable to problems of political economy with lobbying by special interest groups. Establishing sound governance in the field of capital controls would be akin to establishing sound governance in any other area: the regulators responsible would seek to demonstrate that a minimal intervention is being undertaken in response to an identifiable market failure. ${ }^{1}$

A regulatory framework for capital controls that conforms to best practices would have four elements: (i) precise definitions of proposed interventions; (ii) proposed rules governing conditions under which these precise actions should be taken; (iii) demonstration of effectiveness in achieving desired outcomes; and (iv) demonstration that the costs are outweighed by the benefits. To build this regulatory framework, policy-makers would draw on the significant literature that addresses the following four questions: (i) What are capital controls? (ii) Under what circumstances do EME policy-makers use capital controls? (iii) What impact do different capital controls have? and (iv) Do the benefits outweigh the costs?

In this paper, we address the first three of the four questions. We construct a precise vocabulary for classifying all capital control actions (CCAs) on foreign borrowing for India and compile a definitive database about these CCAs. We obtain evidence about the conditions under which policy-makers have used CCAs, distinguishing carefully between exchange rate and macroprudential objectives. Finally, we obtain evidence about the consequences of these actions.

Our focus on India is guided by the literature on capital controls of the 1980s and 1990s, and recent work such as Klein (2012). This literature

\footnotetext{
${ }^{1}$ For more on sound regulatory policy, see, for example, OECD (2012), which recommends that governments adopt a regulatory impact assessment, which would "clearly identify policy goals, and evaluate if regulation is necessary and how it can be most effective and efficient in achieving those goals."
} 
has suggested that once a country achieves an open capital account, episodic introduction of controls is not useful. Hence, if capital controls are to be used as a tool for policy, this has to be done in the context of a comprehensive administrative system for capital controls, where the government has the ability to interfere in all cross-border transactions.

At present, only two large economies have a comprehensive administrative system of capital controls: China and India. Every kind of cross-border transaction is controlled and de jure capital account integration, as measured by the Chinn and Ito (2008) measure, is very low. The empirical evidence drawn from these countries may provide insights on the following four questions: What kinds of interventions have been used? When have they been used? Have they yielded results? Do the benefits outweigh the costs?

The measurement of CCAs is a challenging task. It is extremely difficult to capture the various kinds of capital controls in a simple measure that can be used for empirical analysis. The mainstream cross-country literature has relied on crude indices of capital controls, for example, annual readings in the Chinn-Ito measure. A novel strategy adopted in the recent literature consists of closely examining actions, in contrast to levels studied in the older literature. Studying individual CCAs allows us to observe their precise dates and to precisely classify the nature of the interventions.

Forbes et al. (2013) construct a database of CCAs drawing mainly on data from the IMF Annual Report on Exchange Arrangements and Exchange Restrictions (AREAER) for 60 countries, for the 2009-11 period. While this constitutes better measurement of capital controls, the IMF AREAER data are a coarse measure of CCAs.

A key innovation toward better measurement of CCAs was the data set constructed by Pasricha (2012), which utilizes AREAER, regulators' websites and news sources to identify CCAs in 22 emerging economies. It also counts actions separately by asset class (for example, foreign borrowing, foreign direct investment (FDI), portfolio investments, etc.) and by type (quantitative, price-based, etc.). This reveals a much larger number of CCAs when compared with events reported in the AREAER, and permits better classification of actions, which can then reveal their consequences.

In this paper, we take the next step forward: measuring CCAs with a careful classification of the various aspects of regulations (e.g., controls on minimum maturity of loans, controls on eligible borrowers, interest rate ceilings, etc.). To ensure comprehensive coverage and accurate interpretation of the regula- 
tory actions (including whether the action represented an easing or tightening of controls), we used a legal team that read every legal instrument associated with the CCA. On average, our lawyers spent three man-hours per legal instrument, and constructed a fine-grained data set about CCAs on one asset class: foreign borrowing. Our focus is on foreign borrowing, since it is critically connected with questions of systemic risk.

Our data set covers the period from January 2004 to September 2013 and contains 75 CCAs. It permits us to explore two other main questions in the field. The first finding concerns the circumstances under which EME policy-makers use capital controls on foreign borrowing. The main factor that seems to be at work is the exchange rate. Capital controls are tightened after appreciations and eased after depreciations. Measures of systemic risk do not seem to be a factor shaping the use of capital controls.

What was the impact of these actions? We explore the impact of these actions using event studies. There is a strong selection process at work: CCAs are likely to take place when faced with certain circumstances. Hence, we draw on recent developments in propensity score matching, to match the date on which a CCA was applied against a similar date with no CCA. This permits causal identification of the impact of the CCA. Our results show no impact of the CCAs in any dimension evaluated. We also analyze some sub-categories of controls to determine whether certain kinds of restrictions would be more effective than others, but find no effect in all subsets studied.

The remainder of this paper is organized as follows. Section 2 reviews the existing literature on the four major questions and places our contributions in context. Section 3 describes recent developments in the measurement of CCAs. Section 4 describes the Indian system of capital controls, with an emphasis on capital controls against foreign borrowing, and documents the construction of the novel data set about Indian CCAs on foreign borrowing. Section 5 explains the data and methodologies used in the paper. Section 6 identifies the factors that shape the use of CCAs. Section 7 measures the impact of these actions. Section 8 concludes.

\section{Research questions in the field of capital controls}

In a well-functioning system, the power of the state is located within a framework of objectives, minimal coercive power and accountability mechanisms. 
If capital controls were to become a mainstream tool that is used in a wellstructured regulatory process and conforms to the best practices in regulatory policy, certain conditions would need to be fulfilled. A precise statement of the proposed intervention would be required, along with specification of the conditions under which the restriction would kick in. In order to aid the development of best practices in capital controls policy, the literature needs to address four questions, discussed below.

\subsection{What are capital controls?}

A very wide array of impediments to cross-border transactions are all covered by the broad term "capital controls". For capital controls to establish themselves as part of an optimal policy toolkit, it is important to arrive at precisely articulated interventions and a shared vocabulary, through which these interventions can be discussed, enacted and evaluated.

The literature on the effectiveness of capital controls has been based on measures of capital controls that are too broad to provide useful guidance to regulators about the impact of specific interventions. ${ }^{2}$ Emerging economies use many different types of regulations on cross-border transactions, ranging from quantitative controls (for example, on foreign investment in the securities market), to price-based restrictions (such as the maximum interest rate payable on foreign borrowings) and approval and reporting requirements. Further, the literature on capital controls in the 1980s and 1990s, and recent work such as Klein (2012) emphasize that controls introduced episodically are not effective. Hence, if capital controls are to be useful in meeting the goals of economic policy, there needs to be a comprehensive administrative system for capital controls, where the government has the ability to interfere in all cross-border transactions.

These considerations suggest that in order to provide useful guidelines to regulators, the literature on capital controls needs to specify, categorize and assess the full array of restrictions on cross-border regulations. As mentioned in the introduction, a recent wave of literature has started this process (Pasricha, 2012; Hutchison et al., 2012; Forbes et al., 2013). We go further in this direction by constructing a fine-grained data set of capital control actions (CCAs) that separately classifies every aspect of regulation in India related to foreign borrowing.

\footnotetext{
${ }^{2}$ See Magud et al. (2011) for a survey. The exceptions are some country specific studies, most of which assess the impact of unremunerated reserve requirements or inflow taxes in Latin American countries.
} 


\subsection{Under what circumstances do EME policy-makers use capital controls?}

Do EME policy-makers use capital controls to achieve exchange rate objectives or to pursue systemic risk objectives? Factually assessing the motivations for past EME CCAs can help inform the debate on capital controls, as well as the resulting international consensus on the rules of governance for their use. One the one hand, if it can be discerned in the data that emerging markets have, in fact, been using capital controls to target systemic risk, this bolsters the legitimacy of the EME case for continued use of these instruments. On the other hand, if the data suggest that CCAs have been used for currency manipulation, this bolsters the case of those who argue that further international discussions on the rules of the game are needed to address multilateral concerns.

The recent debate has almost entirely focused on what emerging economies should do; evidence of what motivates their actions is a nascent area of research. Pasricha (2012) uses data on CCAs on a broad range of international capital transactions for 18 EMEs over the period 2004-10 and finds that the use of CCAs follows trends in net capital inflows - measures to reduce net capital inflows were at their peak in 2007 and 2010, when net capital inflows to EMEs were at their peak. Pasricha also finds that the majority of CCAs were not "prudential-type measures," i.e., they were not directly targeted to address a buildup of financial risk. Aizenman and Pasricha (2013) focus on only CCAs on outflows by residents and find that these were also motivated by net capital inflow pressures. Fratzscher (2012) uses the measures of de jure levels of capital controls (Chinn-Ito (2008) and Schindler (2009) indices) to assess macroprudential vs. exchange rate objectives and finds that exchange rate and overheating pressures primarily drove CCAs in a broad sample of countries. This paper uses an event study to provide a systematic evaluation of macroprudential vs. macroeconomic objectives using detailed data on a type of instrument - controls on foreign borrowing - that, in principle, would be well-suited to address systemic-risk concerns.

\subsection{What impact do different capital controls have?}

Empirical evidence about the impact of each type of capital control on macroeconomic outcomes and vulnerabilities in the financial system would provide us with an understanding of the conditions under which different kinds of capital controls are appropriate. This understanding can then be 
translated into optimal rules for financial regulators.

Ostry et al. (2012) find a statistically significant association between financial sector-specific capital controls and lower foreign exchange borrowing. Empirical analysis by Ostry et al. (2010) suggests that countries with controls on debt flows fared better during the recent global financial crisis. However, empirical analysis by Blundell-Wignall and Roulet (2013) qualifies these results, finding that while certain kinds of restrictions on inflows (particularly debt liabilities) were most useful in good times, lower controls on bonds and on FDI inflows were associated with better growth outcomes during the recent global financial crisis period. Our data set allows us to capture precisely the nature of and dates of each of the CCAs, so that their impact on different macroeconomic and financial variables can be isolated in an event study setting.

\subsection{Do the benefits outweigh the costs?}

Cost-benefit analyses allow us to weigh the microeconomic and political economy problems associated with capital controls against the putative gains. Cost-benefit analysis is a key mechanism for improving the quality of work in the regulation-making process and much remains to be done in the area of capital controls. Such an assessment, however, is also beyond the scope of this paper. ${ }^{3}$

\section{Measurement of capital control actions}

An assessment of the motivations for and effectiveness of capital controls is complicated by the challenges involved in the measurement of capital control actions (CCAs). It is extremely difficult to capture the various kinds of capital controls in a simple measure that can be used for empirical analysis.

\footnotetext{
${ }^{3}$ On the cost-assessment side, a wide body of research on capital controls focuses on microeconomic distortions from capital controls (Edwards and Ostry, 1992; Edwards, 1999; Forbes, 2005, 2004). On the benefits side, the evidence is mixed regarding the extent to which capital controls are able to deliver on the objectives of macroeconomic policy. While capital controls seem to be able to change the composition of flows toward more long-term debt, it is not clear to what extent this represents a mislabelling of flows (Magud et al., 2011; Carvalho and Garcia, 2008). Patnaik and Shah (2012) find that the Indian capital controls are not an effective tool for macroeconomic policy.
} 
Figure 1 De jure measures of capital account openness: India

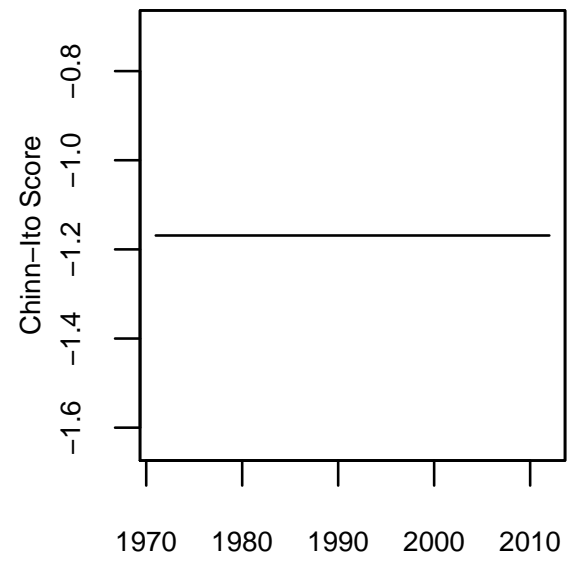

(a) Chinn-Ito measure

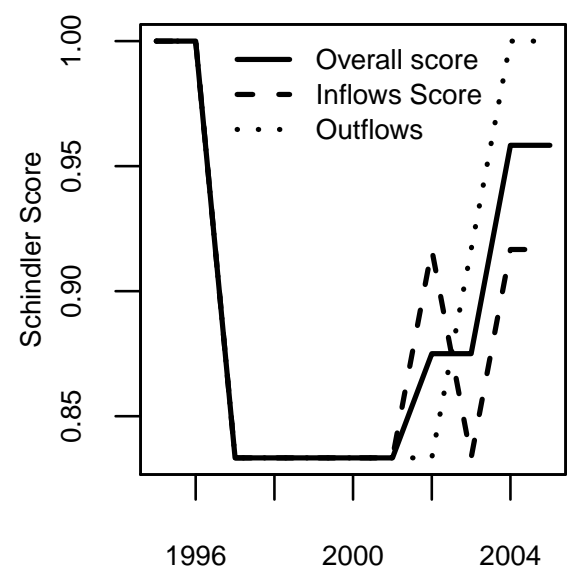

(b) Schindler measure

The mainstream cross-country literature has relied on crude indexes of capital controls. Existing measures of de jure capital account openness, such as the Chinn and Ito $(2008)^{4}$ and the Schindler (2009) indexes, ${ }^{5}$ measure the level of capital controls using the summary classifications table published by the IMF in the AREAER. ${ }^{6}$ While these measures are easily compiled and helpful in cross-country comparisons, they do not capture the complexity of capital controls, particularly when a complex administrative system of capital controls is in place.

As Figure 1 shows, the Chinn and Ito (2008) measure does not detect any change in India's level of openness, i.e., no change in capital controls, for the entire time series from 1970 to 2010. The Schindler (2009) measure appears to do better, by showing at least some variation in the level of openness, but the observed variation is very minor compared with the changes that have taken place in the regime between 1995 and 2005 that are better reflected in the India-specific indexes constructed by other papers (Hutchison et al., 2012; Jadhav, 2003).

\footnotetext{
${ }^{4}$ The Chinn-Ito measure ranges from -1.83 to 2.53 , with -1.83 being a closed capital account economy and 2.53 being an open economy.

${ }^{5}$ The Schindler measure ranges from 1 to 0 , with 1 being a closed capital account economy and 0 being an open economy.

${ }^{6}$ The IMF has been reporting on exchange arrangements and restrictions from 1950 onward and provides a description of the foreign exchange arrangements, exchange and trade systems, and capital controls of all IMF member countries. The AREAER has provided a summary of capital controls for a wide cross section of countries since 1967.
} 
The problem with measures based on the AREAER classification table is that they detect a move toward capital account openness only when an entire sub-category of controls is dismantled. In cases of countries like India, the process of capital account liberalization has gone from complete prohibitions to complex bureaucratic procedures. The process has generally moved toward greater capital account openness, but without dismantling the structure of controls. This allows authorities to retain their ability to reverse past liberalizations. These complexities are hard to capture in summary measures such as those of Chinn and Ito (2008) and Schindler (2009). Another constraint with these databases is their frequency: they report one value every year. This prevents the use of high-frequency data in analyzing the impact of changes in capital controls.

A key innovation of the recent literature is its shift in focus from the level of capital account openness to individual capital control actions (CCAs). Although it may be hard to quantify the extent of restrictions present at a point in time, it is more feasible to unambiguously identify the date of a CCA, and to place it within a classification system. This permits the analysis of changes in the system of capital controls, using high-frequency data and high-quality measurements of each CCA.

This strategy is used by Forbes et al. (2013), which is primarily based on the AREAER, supplemented with news sources. This paper covers 60 countries for a short window of time (2009-11). For example, this data set contains seven actions - five easings and two tightenings - for India.

Pasricha (2012) constructs a fine-grained database of CCAs in 22 emerging markets for the period 2004-10. This paper also uses data from AREAER, but extends it by obtaining information on similar measures from websites of central banks and other regulators, news sources, and other research papers. To increase comparability among actions, capital control changes announced on the same date are broken down by the asset classes that they affect (e.g., portfolio flows, FDI, etc.) and the type of change (quantitative, monitoring or price-based), and each is counted as a separate action. For example, for 2009-11, this data set (extended in Hutchison et al. (2012)) contains 27 actions relating to inflow controls for India, out of which 9 relate to foreign borrowing restrictions.

In this paper, we take the next step by constructing a high-quality data set on CCAs. The classification system tracks changes in each aspect of regulations on foreign borrowing. For example, changes in quantitative limits on foreign borrowing are counted independently of changes in permissible end-uses of the funds borrowed, even if announced on the same date. This yields a 
finer classification system for these actions. For example, for capital controls against foreign borrowing only, for 2009-11, this data set contains 14 actions.

\section{The setting}

\subsection{Capital controls in India}

Capital controls were introduced in India by the British colonial authorities in 1942 as a temporary wartime measure. They gradually evolved into a comprehensive system of restrictions on cross-border capital mobility with the Foreign Exchange Regulation Act (FERA 1973), which criminalized violations. At the time, current account integration was also highly restricted. The conditions associated with a 1991 IMF program required eliminating control of the current account and the capital account. The current account has become open and FERA was replaced by a new law, the Foreign Exchange Management Act (FEMA 1999), under which violations of capital controls were no longer criminal offences, but were civil offences.

All capital account transactions are prohibited unless explicitly permitted. The permissions are granted through a set of legal instruments issued by the Reserve Bank of India (RBI) and the Ministry of Finance. Restrictions differ according to the type of investor, the asset class, the recipient of foreign capital, the intended end-use of the foreign capital, etc.

There are three areas where there are no restrictions on the size of investments: inbound FDI, outbound FDI and foreign investment in the equity market. In all other areas, quantitative restrictions are in place, through which the RBI specifies caps on cross-border activities. For example, there is a cap on the aggregate ownership by all foreign investors of rupee-denominated debt. Similarly, there is a cap on the amount of capital that can be taken out of the country each year by one resident.

There is no unified manual or legal document that shows all the capital account restrictions that are in place. Sinha (2010) is a useful description of the capital controls prevalent in 2010 . 


\begin{tabular}{|c|c|c|c|}
\hline Sub-Category & \multicolumn{2}{|c|}{ ECB } & Trade Credits \\
\hline & Automatic route & Approval route & Automatic route \\
\hline Eligibility criteria to borrow & Eligible borrowers & Eligible borrowers & \\
\hline Controls on eligible lenders & Recognized lenders & Recognized lenders & \\
\hline $\begin{array}{l}\text { Quantitative caps and maturity restric- } \\
\text { tions }\end{array}$ & Amount and maturity & Amount and maturity & Amount and maturity \\
\hline Price ceiling & All-in-cost ceiling & All-in-cost ceiling & All-in-cost ceiling \\
\hline $\begin{array}{l}\text { Permitted activities with foreign ex- } \\
\text { change }\end{array}$ & End-use & End-use & \\
\hline Special route for spectrum auctions & Payment for spectrum allocation & 3G Spectrum allocation & \\
\hline $\begin{array}{l}\text { Activities not permitted with foreign } \\
\text { exchange }\end{array}$ & End-uses not permitted & End-uses not permitted & \\
\hline Guarantees by financial institutions & Guarantees & Guarantees & Guarantees \\
\hline $\begin{array}{l}\text { Nature of security that can be used by } \\
\text { borrowers }\end{array}$ & Security & Security & \\
\hline $\begin{array}{l}\text { Remittance of borrowed funds into In- } \\
\text { dia }\end{array}$ & Parking of ECB proceeds & Parking of ECB proceeds & \\
\hline Early repayment of ECB & Prepayment & Prepayment & \\
\hline Additional ECB for repayment of ECB & Refinancing of an existing ECB & Refinancing of an existing ECB & \\
\hline Interest payment & Debt servicing & Debt servicing & \\
\hline Legal process & Procedure & Procedure & Reporting arrangements \\
\hline Route for distressed corporate entities & Corporations under investigation & & \\
\hline Committee that decides approval route & & Empowered committee & \\
\hline Special approval category & & ECB for rupee loan repayment & \\
\hline Special approval category & & ECB for low-cost housing & \\
\hline
\end{tabular}

\subsection{Capital controls against foreign borrowing in India}

Foreign borrowing with a maturity of less than three years is termed shortdated borrowing, and is prohibited unless it is trade credit. Trade credit can also have a maturity of more than three years.

The remainder - foreign borrowing with a maturity greater than three years that is not trade credit - is termed "external commercial borrowing" (ECB). ECB has, in turn, been broken down into two routes. Some classes of firms are permitted to borrow under certain conditions through an "automatic" window. When these conditions are not satisfied, firms have to apply for "approval" from the RBI.

The regulations are extremely detailed, involving prices (e.g., rules about the highest interest rate that can be paid), quantities (e.g., caps on the magnitude that can be borrowed and the maturity), and industrial policy (firms in certain industries are allowed to borrow, while others are prohibited). Table 1 shows 18 sub-categories of controls, and the treatment of these controls under the automatic and approval route of ECB and under trade credits.

India's restrictions are quite unlike those seen in other EMEs, which have substantially scaled back capital controls as part of the modernization of their economies. For example, successive AREAERs suggest that Chile has had no restrictions on credit from non-residents to residents since 2000. There have been certain registration requirements and withholding tax on interest on loans in Korea, but only notification requirements for large loans. In 
Figure 2 Cumulative borrowing through ECB

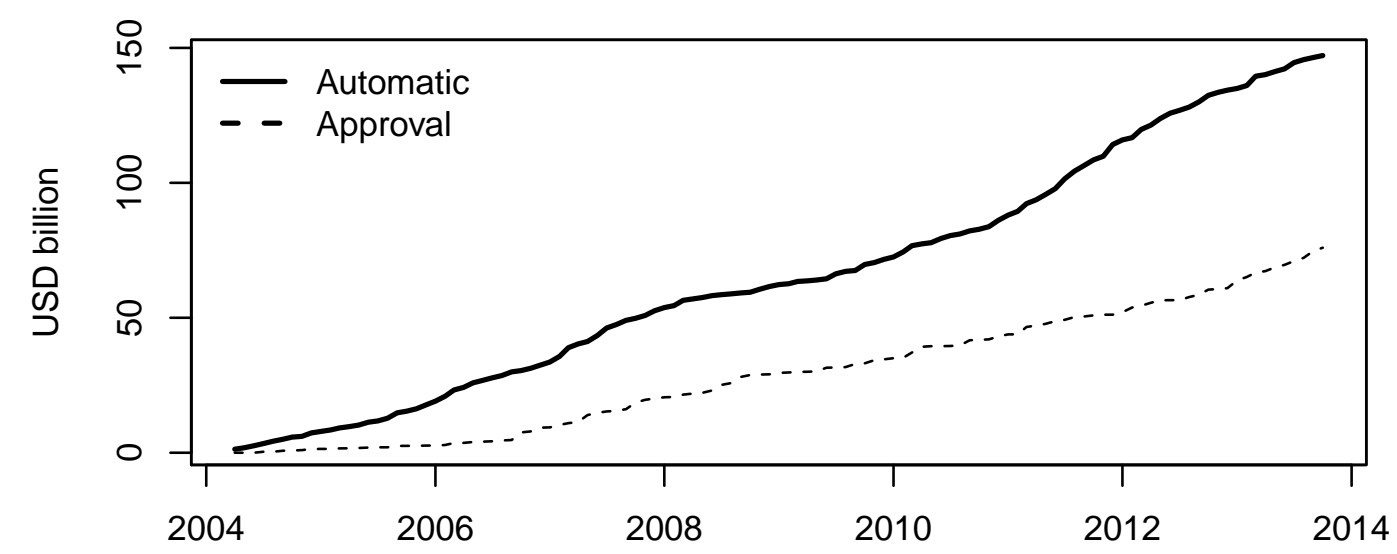

Source: RBI monthly statistics

Mexico, there have been no restrictions imposed except for some limits on foreign currency borrowing by banks as a percentage of their net worth and on their open foreign exchange positions. In Brazil, there have been no controls other than, for some time, a transparent tax on short-term borrowing. And in Turkey, for part of the past decade, there were restrictions in place on foreign currency and foreign currency-linked consumer and mortgage loans.

\subsection{Foreign borrowing in India}

Figure 2 shows the cumulative borrowing that has taken place under ECB (automatic) and ECB (approval) mechanisms over the past decade. The stock of borrowing in March 2013 was 5.4 times that of March 2004. Expressed as a proportion to total external debt, this foreign borrowing rose from 22.9\% in March 2004 to $33.4 \%$ in March 2013.

\section{Data and methodology}

\subsection{The Indian CCA data set}

The RBI is the manager of the FEMA 1999 and has the authority to frame regulations under the Act. Foreign borrowing is governed by foreign exchange 
management (FEM) regulations, which constitute the capital controls on foreign borrowing. Amendments to these regulations must be tabled by the RBI (as notifications) and approved by Parliament in order to be legally enforceable. However, the changes to capital controls are published by the RBI in circulars (and are usually made effective) before the regulatory amendments are passed. The RBI also issues master circulars that act as a compendium of the notifications/circulars issued in the previous year, without necessarily covering all the details.

The practical implication for economists of this complex system is that someone looking at the RBI press releases is likely to miss all the changes in controls. The legal team helped us understand this three-tier system and assisted us in finding all the relevant instruments issued by the RBI over our sample period, i.e., the notifications/circulars and master circulars. They also helped us cross-verify the information in these different instruments, verify that each circular was indeed backed by a notification (regulatory amendment), and verify the effective dates of each change. Further, the legal instruments on capital controls, like the text of other laws and regulations, can be hard for the layman to interpret. For example, for certain actions, it may be difficult for non-experts to correctly understand whether an action represents an easing or a tightening of controls. The legal team also assisted us in this task. Our thorough scan of legal instruments using lawyers' expertise gives us confidence that the resulting database is comprehensive and accurate.

Our database has approximately 100 legal instruments, which represent the full history of capital controls for ECB between January 2004 to September 2013. Even though administrative and procedural changes can have a substantial impact on the ability to undertake transactions, the strategy adopted was to focus only on substantive changes.

Our approach is to count as separate changes in all aspects of controls on foreign borrowing (the regulatory sub-categories in Table 1) even if one or more of these are changed on the same date. Our approach differs from related work in this field. For example, if one RBI circular eases the eligibility criteria for firms allowed to borrow abroad and also eases the maturity restrictions, Pasricha (2012) classifies this as one event. We classify this as two distinct actions. This allows for the analysis of various classes of CCAs on foreign borrowing. ${ }^{7}$

For our empirical analysis, we drop the dates of mixed events, i.e., dates on

\footnotetext{
${ }^{7}$ See Appendix A for further information on our database.
} 


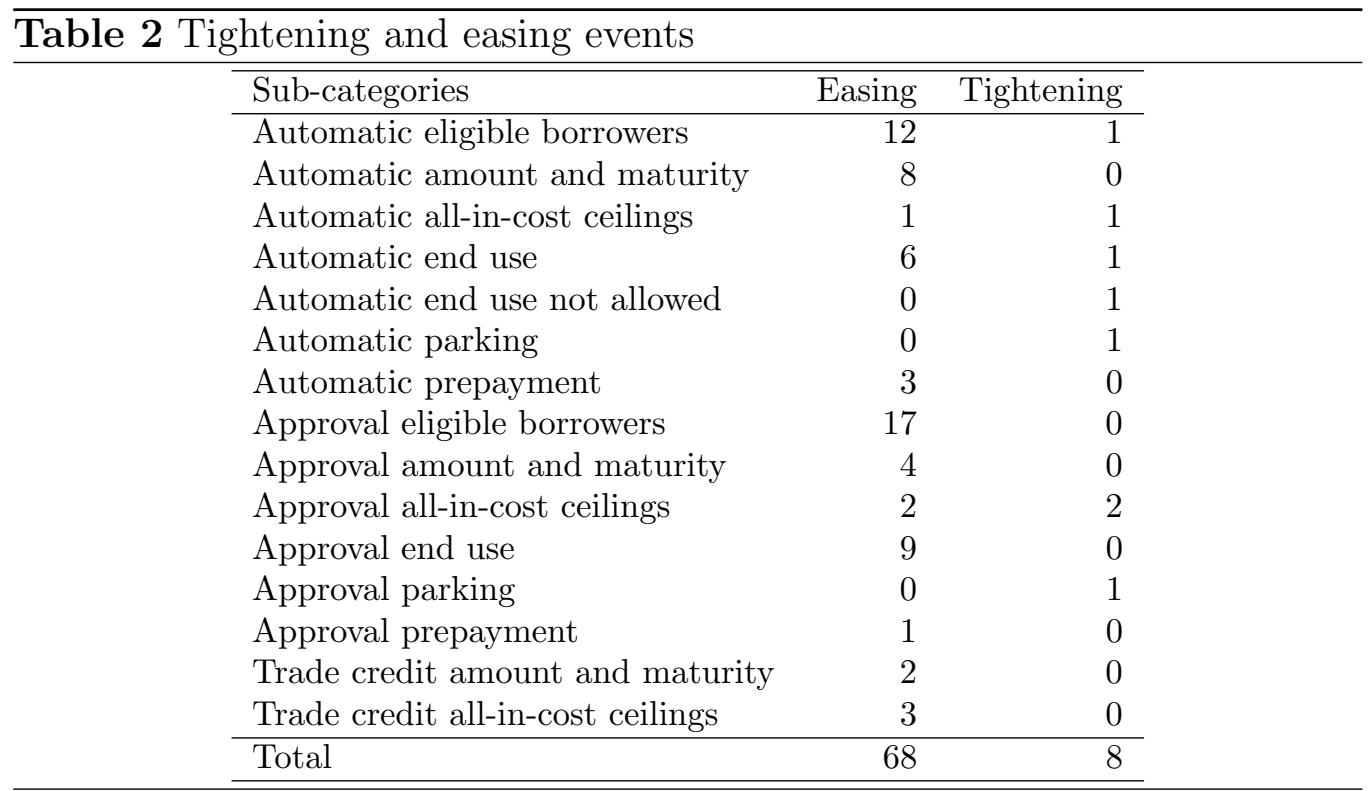

which easing and tightening changes were simultaneously introduced. We also drop those changes on controls in foreign borrowing that overlap with other changes in capital controls. This yields a database of unambiguous changes in capital controls on foreign borrowing with no contemporary confounding events in terms of CCAs.

Table 2 shows summary statistics on our CCA database. Of a total of 76 events, 68 are easing and eight are tightening. The largest number of changes involved the definition of the class of firms that were considered eligible for the automatic route or the approval route. Since most of the records pertain to easing, for much of the analysis that follows in this paper, we analyze easing events only.

Table 3 shows the number of records in the database in each year. The most events occurred in 2012 and 2013, when many CCAs took place to ease controls. However, most tightening events took place in 2007, when net capital inflows to India were surging.

\subsection{Measuring macroeconomic vs. macroprudential objectives}

We use the CCA database to address two questions. First, are CCAs changed in response to macroeconomic management concerns or macroprudential 


\begin{tabular}{|c|c|c|}
\hline Table 3 Number of CCA & s, by year & \\
\hline$\overline{\text { Year }}$ & Easing events & Tightening events \\
\hline 2003 & 0 & 1 \\
\hline 2004 & 2 & 0 \\
\hline 2005 & 6 & 0 \\
\hline 2006 & 2 & 0 \\
\hline 2007 & 1 & 6 \\
\hline 2008 & 8 & 0 \\
\hline 2009 & 0 & 0 \\
\hline 2010 & 8 & 1 \\
\hline 2011 & 6 & 0 \\
\hline 2012 & 20 & 0 \\
\hline 2013 & 15 & 0 \\
\hline Total & 68 & 8 \\
\hline
\end{tabular}

management concerns? Second, what impact did the CCAs have on macroeconomic and financial variables?

In order to address these questions, we need to distinguish between variables that represent macroeconomic management objectives from those that represent macroprudential objectives. A joint report by the Bank for International Settlements (BIS), Financial Stability Board (FSB) and IMF (BIS et al., 2011) carefully makes this distinction. In their analysis, macroprudential policy is defined by its objective of addressing systemic risks in the financial sector to ensure a stable provision of financial services to the real economy over time. They also recommend that macroprudential policy not be burdened with additional objectives, for example, exchange rate stability or stability of aggregate demand or the current account. This recommendation reflects the emerging consensus view of the best practices in macroprudential policy at advanced-economy central banks (Bank of England, 2009; Nier et al., 2013). ${ }^{8}$ The view that macroprudential policy be primarily accorded the objective of systemic risk mitigation allows for the use of capital controls as one of the tools for achieving this objective. However, under this framework, assessing whether capital controls have been used as "macroprudential tools" would necessitate the assessment of systemic risk buildups around the

\footnotetext{
${ }^{8}$ This consensus in advanced-economy and multilateral institutions is in contrast to some of the recent economics literature (and indeed the views of some EME policy-makers) that continues to view exchange rate stabilization and other macroeconomic management objectives as part of the goals of macroprudential policy. For example, Blanchard (2013) suggests an approach where monetary policy, exchange rate intervention, macroprudential measures and capital controls are all used to manage the exchange rate, and this is justified in order to prevent large exchange rate changes that are thought to cause disruptions in the real economy and in financial markets.
} 
time that controls were changed.

In this paper, we follow the BIS-FSB-IMF approach and distinguish between macroeconomic objectives (exchange rate pressures) and macroprudential objectives. We use four outcome variables to assess exchange rate objectives:

1. INR/USD returns: This variable is the daily percentage change in the spot exchange rate of the Indian rupee (INR) against the U.S. dollar (USD). ${ }^{9}$

2. Frankel-Wei residual: Consider the exchange rate regression in Haldane and Hall (1991) that gained prominence after it was used in Frankel and Wei (1994). An independent currency, such as the Swiss franc (CHF), is chosen as an arbitrary "numeraire," and the regression model is

$d \log \left(\frac{\mathrm{INR}}{\mathrm{CHF}}\right)=\beta_{1}+\beta_{2} d \log \left(\frac{\mathrm{USD}}{\mathrm{CHF}}\right)+\beta_{3} d \log \left(\frac{\mathrm{JPY}}{\mathrm{CHF}}\right)+\beta_{4} d \log \left(\frac{\mathrm{DEM}}{\mathrm{CHF}}\right)+\epsilon$

The $\epsilon$ of this regression can be interpreted as the India-specific component of fluctuations in the INR/USD exchange rate.

3. Exchange market pressure (EMP) index: This variable is the Felman and Patnaik (2013) measure of exchange market pressure expressed in terms of per cent change in exchange rate at a monthly frequency. It measures not only how much the exchange rate actually moved, but also how much it would have moved had the central bank not intervened in the foreign exchange market or changed the interest rates. Positive (negative) values indicate a pressure to depreciate (appreciate).

4. Real effective exchange rate (REER): This variable is the trade-weighted average of nominal exchange rates adjusted for the relative price differential between the domestic and foreign countries.

All exchange rate variables are defined such that an increase in value corresponds to a depreciation of the Indian rupee, except the REER, in which an increase corresponds to appreciation. ${ }^{10}$

To assess macroprudential objectives, we use the following variables:

1. Foreign borrowing (or external commercial borrowing, ECB): This is the month-over-month growth in foreign borrowing under the automatic and approval route.

\footnotetext{
${ }^{9}$ The exchange rate against the U.S. dollar is the key rate for the Indian economy. The $\mathrm{RBI}$ intervenes to mitigate volatility in this rate.

${ }^{10}$ The data sources for all variables are in Appendix B.
} 
2. Private bank credit growth: This is the month-over-month percentage growth of non-food credit extended by the banking sector. In order to avoid the confounding effects of the highly volatile inflation time-series, credit growth is re-expressed in real terms.

3. Stock price returns: This is the daily percentage change in the $\mathrm{S} \& \mathrm{P}$ CNX Nifty closing prices.

4. Gross capital inflows: This is the quarter-over-quarter growth in gross flows on the financial account of balance of payments.

5. M3 growth: This is the month-over-month growth in the money supply.

\subsection{Methodology: Motivations for CCAs}

We approach the question of what motivates the use of CCAs in two ways. The first approach involves using both sets of outcome variables (measuring exchange rate and macroprudential objectives) in a logit model explaining easing of controls. ${ }^{11}$ If only exchange rate variables are significant and of the right signs, we may infer that the exchange rate motivations are predominant. The logits are done at a weekly frequency and three lags of each of the outcome variables are used. The weekly frequency puts a constraint on the outcome variables we may use in the logits. We also provide results for logits at a monthly frequency. ${ }^{12}$ The results are unchanged. For the exchange rate objective, we use two specifications: (i) the spot returns, and (ii) the predicted portion and the residual from the exchange rate regression used in Frankel and Wei (1994). To proxy concerns about buildup of financial imbalances, we use growth in the money supply (M3) and the stock market (Nifty) returns.

The second approach is an event study that looks for statistically significant trends in each of the outcome variables in the period leading up to the event date, which is the date of the CCA. One the one hand, if the CCAs are used as a tool for exchange rate policy, then foreign borrowing is restricted when there is pressure to appreciate, and vice versa. On the other hand, a macroprudential regulator would tighten controls on foreign borrowing in response to evidence of excessive foreign borrowing, excessive currency mismatches or asset price bubbles. The testable hypotheses (expected trends) for each of our outcome variables are summarized in Table 4.

\footnotetext{
${ }^{11}$ There are not enough tightenings in the sample for a robust logit analysis.

${ }^{12}$ The results are not sensitive to the choice of lag. We tried specifications with one to four lags for weekly specification and up to three lags for monthly specification.
} 
The horizon over which we assess the trends in each variable when assessing motivations for CCAs is, in general, shorter for the exchange rate variables than for the systemic risk variables. The administrative infrastructure for the controls is well established: the RBI has autonomy on foreign exchange management, and it is able to provide notification of changes with immediate effect via circulars and later issue regulatory amendments that have already been approved by Parliament. Further, RBI actions on capital controls take place quite frequently. Therefore, we think that the appropriate time horizon for assessing the exchange rate is no more than three months, but potentially shorter. The same holds for market-based variables such as stock prices. For the other variables, such as bank credit growth, which are slower moving and for which information is available only with a lag, we evaluate indicators over a longer horizon before the event, up to six months (for foreign borrowing or bank credit growth) or two quarters (gross capital flows).

For the event study, mean adjustment is used in all cases, where the time series of (cumulative) percentage changes is de-meaned. Using cumulative changes rather than actual changes allows us to control for the fact that some of the announcements may be anticipated (Kothari and Warner, 2007). ${ }^{13}$ Using non-cumulative changes would put too much weight on the behaviour of the series very close to the announcement of the capital control action (CCA).

To test for statistical significance, the bootstrap procedure for event studies described in Davison et al. (1986) is utilized. ${ }^{14}$ Inference procedures in traditional event studies were based on classical statistics (for example, the $t$-statistic). However, classical statistics require distributional assumptions, including normality, independence and lack of serial correlation. Further, the asymptotic properties of the test statistics do not apply for small samples. A large literature has shown that bootstrap methods allow more robust inferences for event studies. ${ }^{15}$ The bootstrap approach avoids imposing distributional assumptions such as normality, and is also robust against serial correlation - the latter being particularly relevant in the context of macroeconomic variables like exchange rate and foreign inflows.

The bootstrap inference strategy that we use is as follows:

1. Suppose there are $N$ events. ${ }^{16}$ Each event is expressed as a time series

\footnotetext{
${ }^{13}$ For all the changes in our sample, the announcement dates were also the effective dates of the changes.

${ }^{14}$ The program is described in Patnaik et al. (2013) and Anand et al. (2014).

${ }^{15}$ See Kothari and Warner (2007) and references therein.

${ }^{16}$ Note that the event study is done at the level of events, not weeks or months. This
} 


\begin{tabular}{clll}
\hline Table 4 Event study for capital controls motivation: Expected trends \\
\hline \multicolumn{1}{l}{ Variable } & \multicolumn{2}{c}{ Trend prior to } \\
\cline { 2 - 3 } Exchange rate objective & Easing & Tightening \\
\cline { 2 - 3 } INR/USD returns & Depreciation & Appreciation \\
Frankel-Wei residuals & Depreciation & Appreciation \\
Exchange market pressure & Depreciation & Appreciation \\
REER & Depreciation & Appreciation \\
& & \\
\hline Macroprudential objective & Easing & Tightening \\
\hline Foreign borrowing (ECB) & Slowing & Increasing \\
Bank credit growth & Slowing & Increasing \\
Gross inflows & Slowing & Increasing \\
Stock price growth & Slowing & Increasing \\
\hline
\end{tabular}

of cumulative changes $\left(C_{t}^{n}, n=1 \ldots N\right)$ in event time, within the event window. The overall summary statistic of interest is the $\bar{C}_{t}$, the average over the $N$ time series.

2. We do sampling with replacement at the level of the events. Each bootstrap sample is constructed by sampling with replacement, $N$ times, within the data set of $N$ events. For each draw, the $C_{t}^{n}$ time series corresponding to one event is taken, and $N$ such draws are made. Averaging over the $N$ draws, this yields a time series $\bar{C}_{1 t}$, which is one draw from the distribution of the statistic.

3. This procedure is repeated 1,000 times in order to obtain the full distribution of $\bar{C}_{t}$. Percentiles of the distribution are shown in the figures reported later in the paper, giving bootstrap confidence intervals for our estimates.

\subsection{Methodology: Effectiveness of CCAs}

To study the effectiveness of capital controls we use two methodologies. First, we conduct event studies starting from the event date, i.e., the date of a CCA. The event studies are done separately on both easing and tightening events, for all events included in the sample. Table 5 presents the testable hypotheses (expected trends) with respect to each of the outcome variables under the assumption that capital controls were effective.

For the event studies of the effectiveness of CCAs, the horizon again depends

means that a week in which there is more than one event is included in the sample as many times as there are events in that week. 


\begin{tabular}{|c|c|c|}
\hline \multicolumn{3}{|c|}{$\begin{array}{l}\text { Table } 5 \text { Event study for capital controls effectiveness: Expecte } \\
\qquad \text { Variables } \\
\text { Expected impact of }\end{array}$} \\
\hline Exchange rate objective & Easing & Tightening \\
\hline INR/USD returns & Appreciation & Depreciation \\
\hline Frankel-Wei residuals & Appreciation & Depreciation \\
\hline Exchange market pressure & Appreciation & Depreciation \\
\hline REER & Appreciation & Depreciation \\
\hline Macroprudential objective & Easing & Tightening \\
\hline Foreign borrowing (ECB) & Increase & Decrease \\
\hline Bank credit growth & Increase & Decrease \\
\hline Gross inflows & Increase & Decrease \\
\hline Stock prices & Increase & Decrease \\
\hline
\end{tabular}

on the variables, and is shorter for higher-frequency variables. For spot exchange rates, Frankel-Wei residuals and stock prices that are forward-looking market variables, and for which daily data is available, we use a horizon of seven days after the change. The full expected impact of the CCAs on these variables will be immediately reflected in the market prices. For the other variables, we keep the same horizons that we used for the motivations event study, i.e., three months for REER and exchange market pressure indexes and six months or two quarters for gross inflows, foreign borrowings and bank credit.

While an event study with all CCAs allows us to identify changes in a series after a CCA, it does not allow us to make causal inferences unless the CCA is randomly assigned. If the regulators use capital controls for macroprudential purposes, or for exchange rate management purposes, then there will be a selection bias. The weeks in which CCAs were implemented will differ in identifiable ways, from weeks in which CCAs were not implemented. In the regression:

$$
Y_{t}=\alpha+\beta C C A_{t}+\epsilon_{t}
$$

where $Y_{t}$ is the macroeconomic variable of interest (for example, the exchange rate returns), the dummy variable $C C A_{t}$ will be correlated with the error term $\epsilon_{t}$.

One way to assess the causality is to add other variables $X_{t}$ to equation (1), conditional on which the CCA is assumed to be "as good as randomly assigned". The conditional effect of capital controls in this multivariate regression is then interpreted to be the causal impact. The propensity score matching (PSM) methodology is an alternative way of building the counterfactual. Instead of trying to model the outcome variables, we model the 
policy variable - the use of a CCA — and estimate the conditional probabilities for the use of CCAs. These conditional probabilities, called propensity scores, are used to identify time periods that had similar characteristics to those prior to the date of the CCA but where no CCA was employed (control group). The behaviour of the outcome variables for the control group gives us a counterfactual for how each of these variables would have behaved had the CCA not been employed. We then compare the outcomes in the weeks after the CCA between the treatment and control groups.

The conventional use of PSM is for cross-sectional data, such as firm or household data, where a selection process has identified some units for a treatment. A logit (or probit) regression is utilized to characterize the selection process. Units with a proximate value of the propensity score have a similar probability of being treated, but some are treated and some are not. Untreated units with propensity scores similar to treated units therefore serve as the counterfactual. This strategy has been extended to identifying time periods as controls (Angrist and Kuersteiner, 2011; Moura et al., 2013; Aggarwal and Thomas, 2013).

There are several advantages to using PSM rather than multivariate regression in the context of this paper. ${ }^{17}$ First, macroeconomic variables of interest to us, particularly exchange rates and stock prices, are harder to model or motivate than the policy action (CCA). In the PSM, we do not need to assume a linear relationship between the outcome variable and the regressors, nor do we need to specify the lag length of regressors, for example, in the model for exchange rate. By narrowing the focus to policy choice rather than outcome, we may increase robustness. Second, in computing the average treatment effect on the treated, multivariate regressions put greater weight on observations with equal probability of being treated and untreated. These observations may be very different from observations that belong to the treated group. PSM, on the other hand, puts greater weights on observations that had the highest likelihood of being treated, but were not. In other words, PSM puts greater weights on the control observations that were most similar to the treated observation, which can reduce bias. Finally, there can be efficiency gains in the finite sample with PSM (Angrist and Hahn, 2004).

To implement the PSM, there are two choices to make: the model to be used for estimating the propensity scores, and the algorithm to match the treated with the control observations. To estimate the propensity scores, we use the weekly logit model from the motivation section. The explanatory variables

\footnotetext{
17 See Angrist and Pischke (2008); Forbes et al. (2013) for further discussions of the similarities and differences between PSM and multivariate regressions.
} 
used in the logit model are the same as in model 1 of Table 6: exchange rate changes, credit growth, money supply growth and returns on Nifty. ${ }^{18}$

Once we have the propensity scores, there are several algorithms available in the literature to match treated observations with control observations (i.e., to find control observations that are most "similar" to treated ones). We use the nearest neighbour with a caliper algorithm, which matches each treated observation with the control observation that has the closest propensity score, as long as the distance between the two propensity scores is less than the tolerance level (caliper). We test different caliper values and use the value of 0.15 , since it gives us the best match balance (discussed further below). We use nearest neighbour matching without replacement, which means that each control week is matched only once with a treatment week. ${ }^{19}$

There are two key assumptions underlying the PSM analysis: the common support condition and the independence assumption (or the balancing test). The common support condition is that the policy is not perfectly predictable, i.e., that there must be both treated and untreated units for each set of observable characteristics. This assumption can be thought of as applying to either the sample or the population. Nearest neighbour matching with a caliper ensures common support by excluding treated observations for which there is no close enough, untreated neighbour (Caliendo and Kopeinig, 2005).

The balancing test verifies whether the matching algorithm was able to achieve close proximity in the distributions of relevant variables for the treated and control groups. To check for match balance, we first use the visual approach of plotting the cumulative density functions of the propensity scores for the treated and control groups and the full sample. We also use the Kolmorogov-Smirnov test for the equality of distributions in the treated and control groups for a broad set of outcome variables (Sekhon, 2011).

There are 30 weeks in which 68 easing measures are observed. ${ }^{20}$ We delete one week in which there was both a tightening and an easing. We force a

\footnotetext{
${ }^{18}$ As a robustness check, we also try model 2 in Table 6, which uses Frankel-Wei residuals instead of spot returns. This gives us one fewer matched week, but the results from the matched event study are similar.

${ }^{19}$ We also test the robustness of our results to an alternative matching algorithm, genetic matching, which is a generalization of the PSM method (Sekhon, 2011). It is a non-parametric method that tries to obtain a balance based on the observed covariates (the explanatory variables in our logit regressions) between the control and treatment observations, without estimating the logit model. We are able to achieve a match balance for the 29 control weeks using this method and our results are robust to using this alternative method.

${ }^{20}$ See Appendix D for a full list of control and treated weeks.
} 
minimum window of plus or minus four weeks around treatment dates to ensure that treatment and control dates do not overlap. Nearest neighbour matching with caliper gives us 22 matched weeks. ${ }^{21}$ We then do an event study using only these 22 matched pairs. The following sections describe our results.

\section{Results: What motivates CCAs?}

Both logit and event study analysis indicate a predominance of exchange rate motivations for undertaking CCAs, over the period from January 2004 to September 2013.

\subsection{A logit analysis}

When we use both exchange rate and other financial variables together in a logit regression to assess which of the variables are associated with a higher probability of easing of inflow controls, we find that only exchange rate variables are statistically significant. Table 6 shows the results of logit models that explain a dummy variable that is 1 in weeks when an easing CCA is present. Model 1 uses the raw INR/USD exchange rate. The only significant regressors are the INR/USD exchange rate with a lag of one week and three weeks. In both cases, depreciation predicts easing. Model 2 shifts from the raw INR/USD returns to two components: the predicted part and the residual from the exchange rate regression used in Frankel and Wei (1994). At the same two lags (one and three weeks), the residual from the exchange rate regression is statistically significant. Model 3 shows the results of the logit model with variables at monthly frequency. Here we are able to include monthly foreign borrowing flows as one of the explanatory variables. ${ }^{22}$ Again, the only regressor that is significant is the INR/USD exchange rate.

This evidence suggests that RBI eases CCAs on foreign borrowing when faced with currency depreciation. We find no evidence that CCAs respond to credit growth, stock market returns or broad growth in the money supply.

\footnotetext{
${ }^{21}$ If we do not use a caliper, we are able to match all 29 weeks. However, using a caliper gives us a better match balance, and also addresses the common support problem by excluding observations for which there are no close neighbours in the control group. The results of ineffectiveness of CCAs are not sensitive to this choice.

${ }^{22}$ Note that all variables in the monthly logits are measured at a monthly frequency and all variables in weekly logits are measured at a weekly frequency.
} 


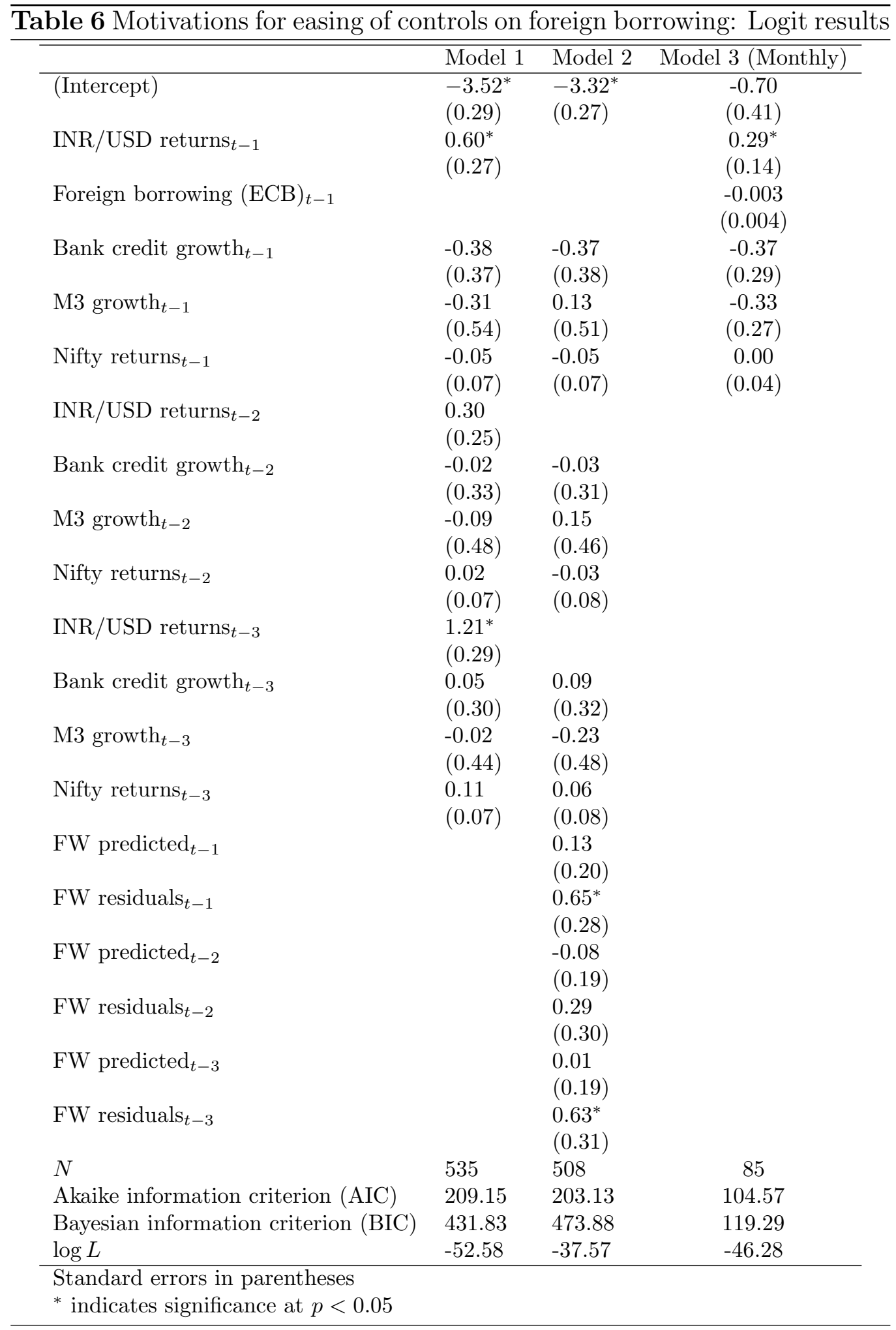




\subsection{Event study approach}

The next step in our analysis of motivations for CCAs is to conduct a series of event studies. This permits careful analysis of one time series at a time, in the period leading up to the event date, which is the date of the CCA. We assess the importance of exchange rate versus macroprudential objectives by testing the significance of trends before the CCA dates using four measures of exchange rates (INR/USD spot returns, Frankel-Wei residuals, the exchange market pressure index and the real effective exchange rate) and four variables to reflect financial stability risks (growth of foreign borrowing, domestic bank credit growth, gross inflows and stock price returns).

\section{Exchange rate objectives}

The mean-adjusted time series of the INR/USD exchange rate returns prior to the CCA dates is shown in Figure 3. The left pane, Figure 3(a), shows the average cumulative return of the INR/USD in the 12 weeks prior to the date on which an easing is announced. There is no significant trend in the exchange rate 12 to 5 weeks before the easing date, but, an average deprecation of $3 \%$ is observed in the 4 weeks preceding the easing of controls. The null hypothesis of no change can be rejected at a $95 \%$ level of significance. The right pane, Figure 3(b), applies the same analysis to tightening dates. The data set here is weaker since we observe only seven dates, which results in a wider $95 \%$ confidence interval. On average, an exchange rate appreciation of $5 \%$ over 12 weeks precedes the tightening date. Here also, the null hypothesis of no change can be rejected at a $95 \%$ level of significance. This suggests that CCAs can be used as a tool for exchange rate policy, and is consistent with the logit model of Table 6 .

The other three measures of exchange rate motivation for CCAs yield similar results (Figures 4 to 6). In all cases, there is a significant appreciation trend for the Indian rupee prior to tightening of inflow controls, and in all but one case, a significant depreciation trend prior to easing of inflow controls. Only for the REER, the depreciation trend prior to easing of inflow controls is not statistically significant at a $95 \%$ level of significance for the threemonth horizon, but would be significant if a two-month pre-event window is considered. On the whole, we interpret these results as strong evidence of exchange rate motivation for capital control actions.

\section{Macroprudential objectives}

If RBI is concerned about the buildup of systemic risk, then there may be a CCA response to foreign borrowing (ECB), private bank credit growth, 
capital flows and stock prices to lean against the wind. The event study results for each of these series are presented in Figures 7 to 10.

In contrast with the results on exchange rate objectives, the evidence in support of macroprudential objectives is mixed. As far as easing of CCAs is concerned, there are no statistically significant trends in three out of the four variables in the periods leading up to easing of inflow controls. The fourth variable, bank credit growth, has a slowing trend prior to easing. There is evidence of increasing foreign borrowing and gross inflows prior to tightening of controls in the full horizon considered (Figures 7 and 9), but in the last two months before tightening, the foreign borrowing is slowing or flat. Further, there is no evidence of increasing stock prices or bank credit growth prior to tightening of controls.

We interpret these results as providing one-sided CCAs and weak evidence of macroprudential concerns driving CCAs, unlike the unambiguous evidence for exchange rate objectives. This conclusion becomes clearer when looking at Table 7, which puts the results for all the variables together, and limits the horizon to one month for the exchange rates and stock prices (since these are faster moving, forward-looking variables), and to three months (one quarter) for the other variables.

As a robustness check, we also split the samples into periods before and after the global financial crisis and conduct the event studies separately on these samples. These robustness checks could be conducted only on the easing side, since all tightenings took place in the pre-crisis period. The results for the post-crisis period (2009-13) for easings are broadly the same as those for the full sample. ${ }^{23}$ For the pre-crisis period, the results are broadly similar, but there are some interesting differences.

For the January 2004-May 2008 period, there are 10 easings in sample, and the results for FW residuals, INR-USD returns and REER are the same as for the full sample (showing depreciation prior to easing), but the trends are not significant. The wider confidence intervals could be due to the smaller number of observations but also due to more variation in the policy. The exchange market pressure index shows a significant appreciation trend in the six months prior to easing, but is stable in the month before easing. On the macroprudential side, foreign borrowing, gross inflows and stock prices continue to show no significant trend in up to two quarters prior to easings,

\footnotetext{
${ }^{23}$ The only difference is for foreign borrowing. For the full sample we see a declining trend in foreign borrowing prior to easing, but for the post-crisis period, we see an increase in foreign borrowing, prior to easing of controls, although the trend is not significant.
} 
as seen for the full sample. However, bank credit growth shows significant trends prior to easings but in the opposite direction. This suggests that not only was policy not countercyclical, it was procyclical at this time. These results seem to bolster our finding that the policy was not systematically driven by macroprudential motivations.

A careful look at the changes allows us to better understand the results for the pre-crisis period. The new ECB regime came into place in 2004, and the changes during 2004-05 seem to be structural changes related to the overall liberalization of the policy. The changes in this period included new types of borrowers under the approval and automatic routes and expansion of the list of allowable end uses. These changes do not seem to be a response to the prevailing macroeconomic conditions, but rather, they seem to reflect the establishment of a new regime of foreign borrowing. If we remove the 2004-05 period, and include the crisis period during which the countercyclicality of policy would have been a priority (January 2006-December 2008), the results are similar to what we obtained for the full sample. As with the full sample, policy seems acyclical (rather than procyclical as seen in the January 2004May 2008 period) with respect to systemic risk variables, with no significant trends in foreign borrowing and bank credit growth, and a barely significant, small decline in stock prices. We see a significant declining trend prior to easing only in gross inflows. For the exchange rate objective, as with the full sample, a depreciation trend is seen in all four variables prior to easing, and it is significant for three out of the four variables.

On the whole, the robustness check confirms our results of the primacy of the exchange rate objective over the macroprudential objective, both in the high-growth pre-crisis period, during the crisis and in the post-crisis period of less-robust growth.

To summarize, evidence from the logit model and the event studies shows a clear role for exchange rate policy in explaining the RBI's use of CCAs. The evidence is less conclusive for variables that may capture macroprudential objectives. These variables are not significant in logit regressions. Further, there are no clear patterns in foreign borrowing or stock price returns prior to changes in controls. We find evidence that easing of controls follows periods of slowing bank credit growth, but the reverse is not true prior to tightenings. There is evidence of tightening of capital controls during periods of increasing gross inflows, but the reverse is not true prior to easings, and moreover, foreign borrowing itself slows in the two months prior to the change. Putting these together, it is hard to conclude that RBI is using CCAs as a tool for systemic risk reduction. Our results suggest that CCAs may be a tool of 
exchange rate policy.

Figure 3 INR/USD fluctuations prior to dates of CCAs

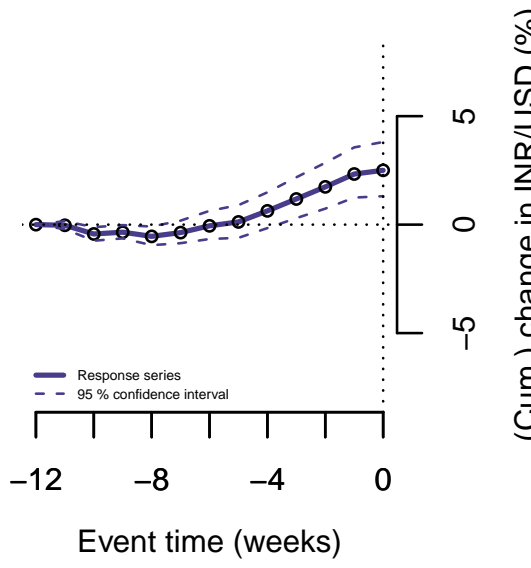

(a) 68 easing events

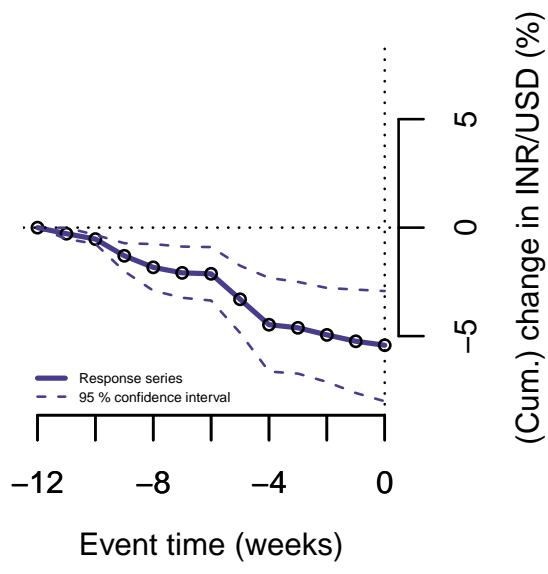

(b) 8 tightening events 
Figure 4 Frankel-Wei (FW) residual fluctuations prior to dates of CCAs

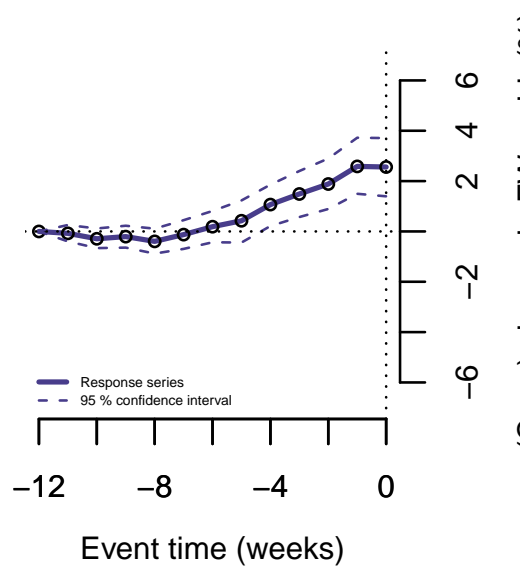

(a) 68 easing events

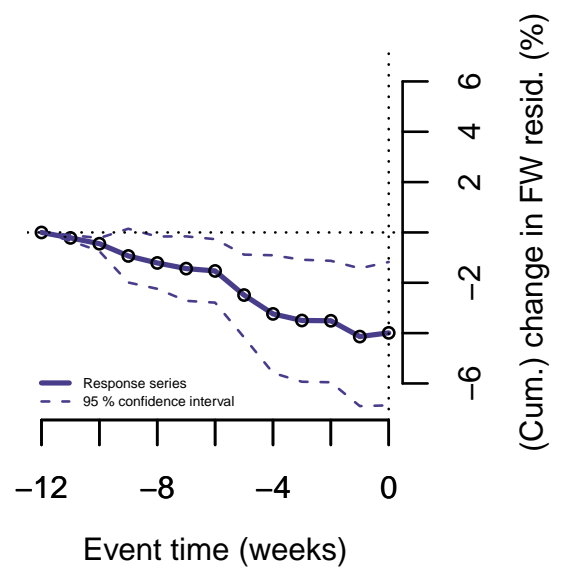

(b) 8 tightening events

$\overline{\text { Figure } 5 \text { Fluctuations in the exchange market pressure (EMP) index prior }}$ to dates of CCAs

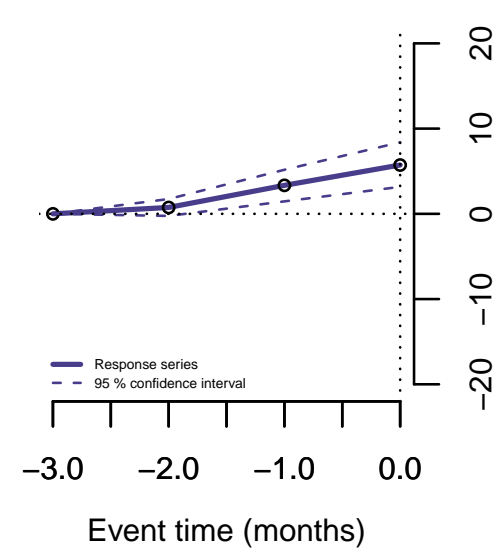

(a) 68 easing events

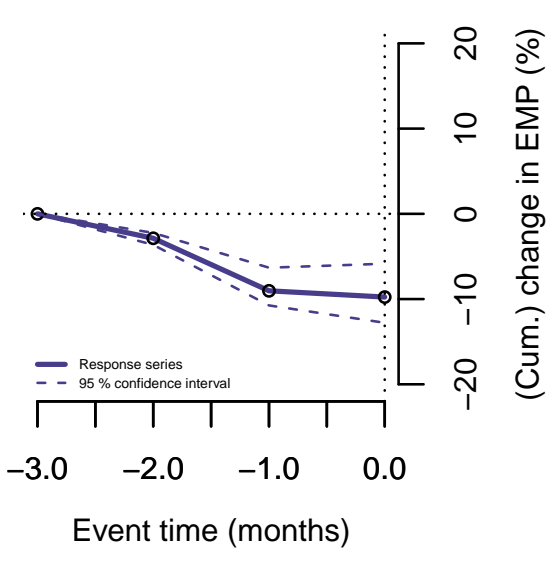

(b) 8 tightening events 
Figure 6 Real effective exchange rate (REER) fluctuations prior to dates of CCAs

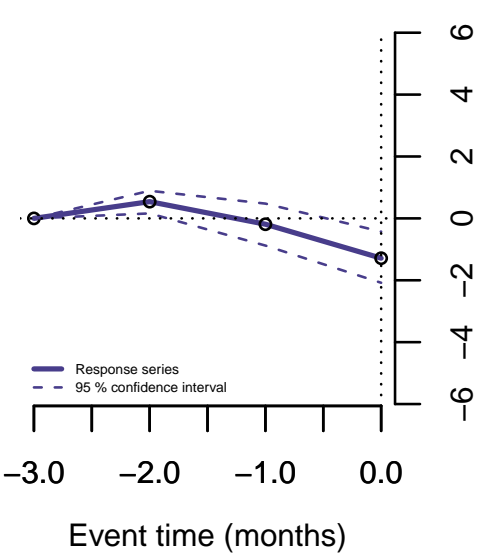

(a) 68 easing events

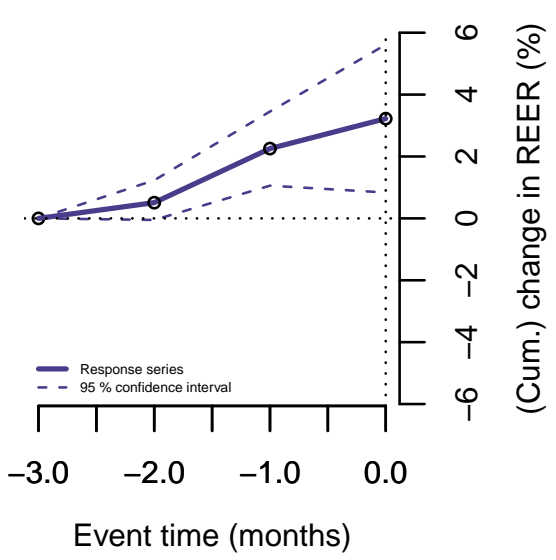

(b) 8 tightening events

Figure 7 Fluctuations in foreign borrowings prior to dates of CCAs

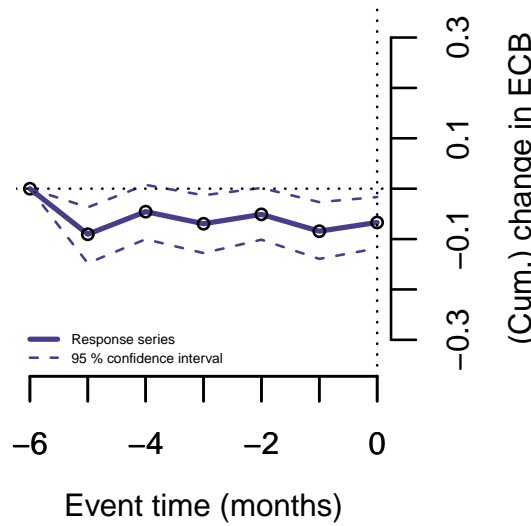

(a) 68 easing events

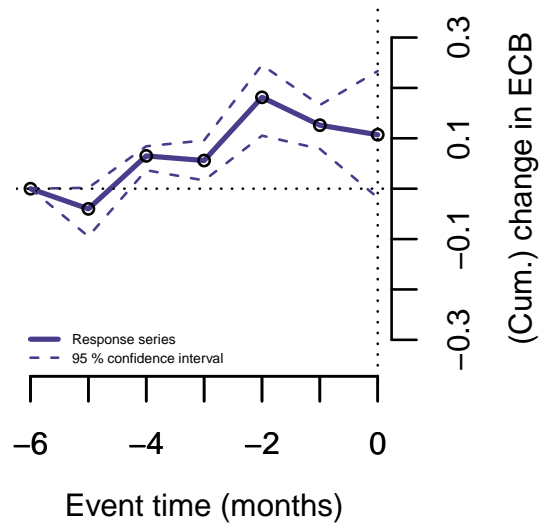

(b) 8 tightening events 
Figure 8 Fluctuations in bank credit growth prior to dates of CCAs

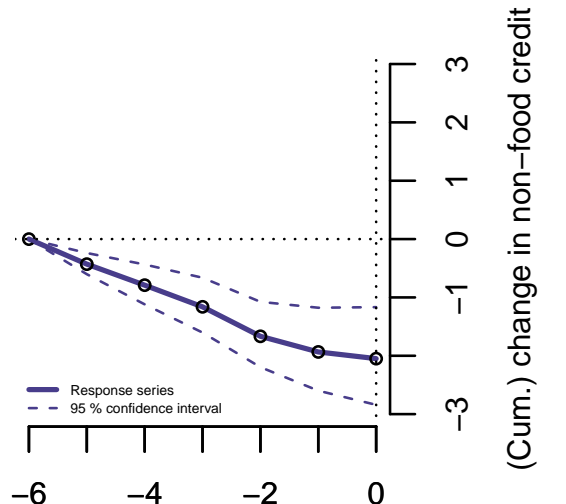

Event time (months)

(a) 68 easing events

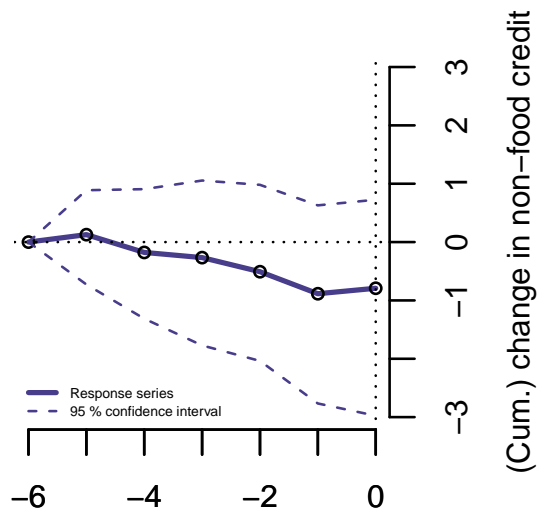

Event time (months)

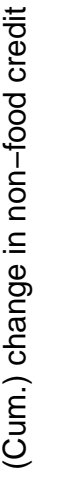

(b) 8 tightening events

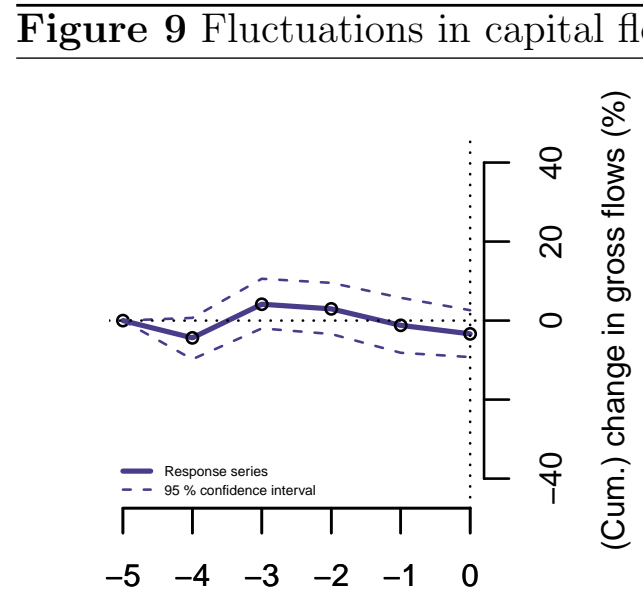

Event time (quarters)

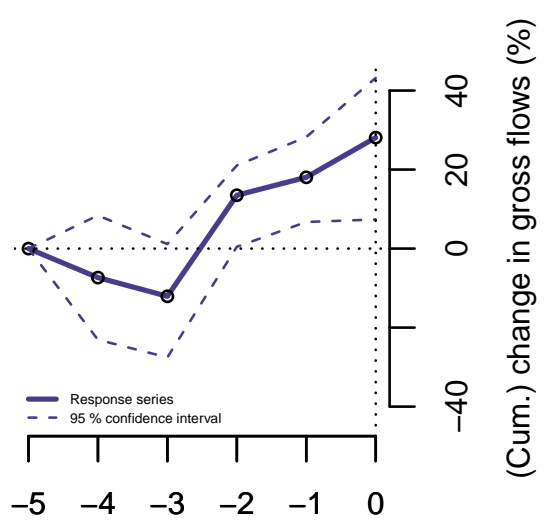

Event time (quarters)
(a) 68 easing events
(b) 8 tightening events 
Figure 10 Fluctuations in stock prices prior to dates of CCAs

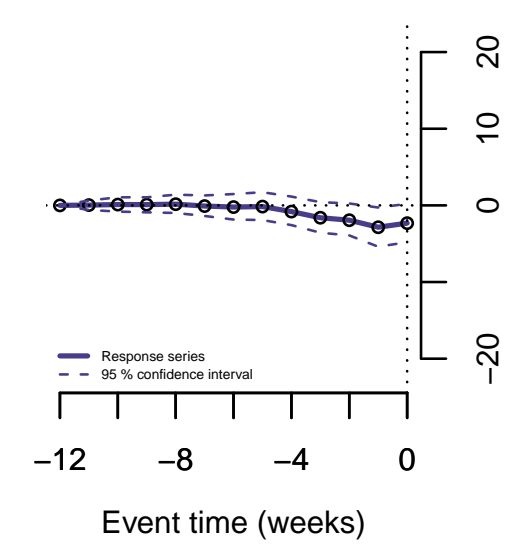

(a) 68 easing events

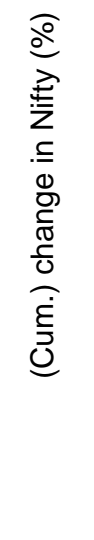

\section{Figure 10 Fluctuations in stock prices prior to dates of CCAs}

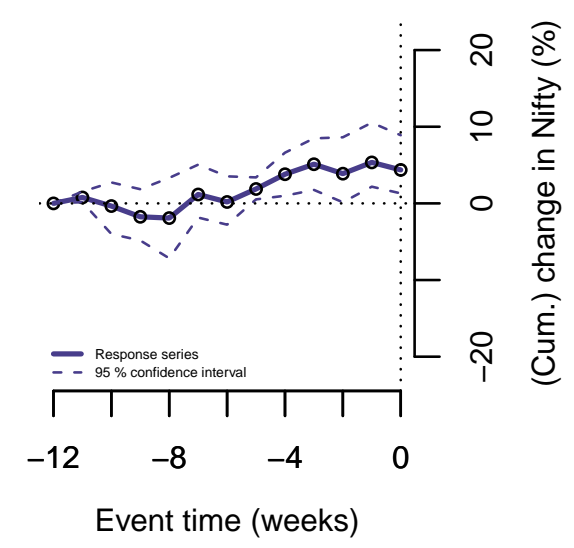

(b) 8 tightening events

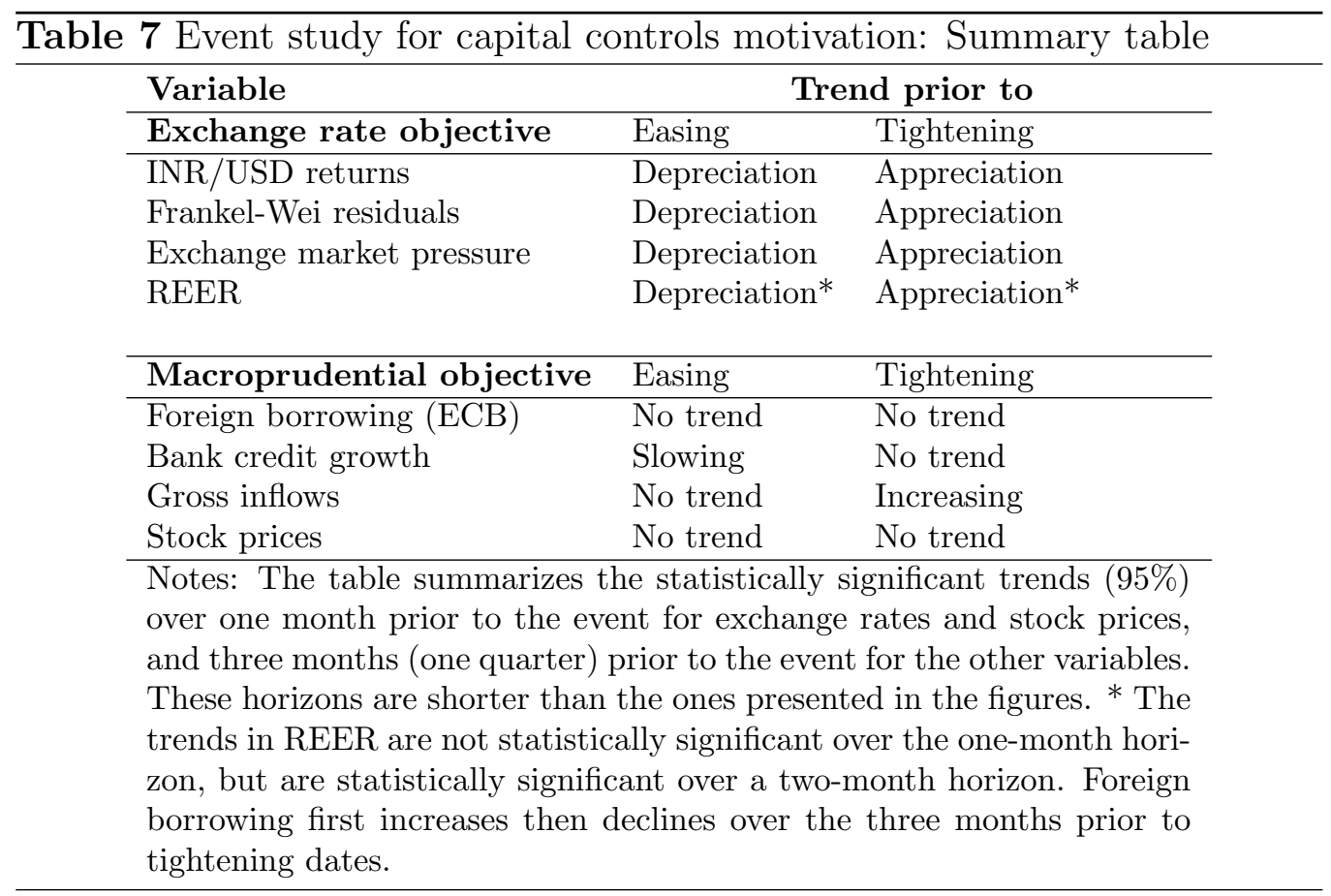




\section{Results: Were the CCAs effective?}

\subsection{Event study approach}

The event study on effectiveness reveals mixed results for the impact on the exchange rate (Table 8 and Figures 11 to 14). On both the easing and tightening side, for three outcome variables - INR/USD returns, FrankelWei residuals and REER - the post-event mean is no different from the mean at the event date. ${ }^{24}$ Putting this result in the context of results from the previous section, which showed a steady depreciation trend prior to easing, one could infer that CCAs are able to halt the slide in the exchange rate. However, there is no impact on the exchange market pressure, i.e., the preevent trend continues unabated post event, for both easing and tightening events. This suggests that the halt in spot exchange rate depreciation may simply reflect greater use of foreign exchange reserves following the event, rather than an impact of the event itself. ${ }^{25}$ All together, the results are at best ambiguous and we do not view them as suggesting a clear benefit (in terms of exchange rate management) from the use of capital controls.

For the variables representing macroprudential objectives, the evidence for the effectiveness of capital controls is also thin (Figures 15 to 18). Easing of controls does not have any impact on foreign borrowing (which increases at month 1 after the event but falls back thereafter) or gross inflows. Further, the growth of bank credit continues its pre-easing downward trend. Stock prices, however, do show a small increase in the three days after the easing of controls, suggesting the possibility of a positive but short-lived confidence effect.

Tightening of capital controls is associated with a significant decline in foreign borrowing in the five months after tightening events. Further, tightening of capital controls are followed by strong growth in bank credit (from no trend prior to the event). Together, the two results could suggest a decline in riskiness of overall credit growth with foreign currency borrowing replaced by domestic currency borrowing. However, gross inflows continue to increase over this period (two quarters). While these trends could be consistent with

\footnotetext{
${ }^{24}$ The results on the insignificant difference in mean returns of the spot exchange rate post-event are not driven by higher volatility of the exchange rate post-event. See Appendix B.

${ }^{25}$ This conclusion has been verified through an event study on foreign exchange reserves. Prior to easings, foreign exchange reserves were declining and they continued to decline post-easing. The reverse held for tightening events.
} 
the desired outcome of the change in relative composition of inflows toward less-risky forms, they could also be due to a mislabelling of flows as a means to evade tighter controls. Further, there are very few tightening events in the sample, and we do not obtain parallel results with the more numerous easing of controls, which have no impact on each of these series. There is a short-lived decline in stock prices in the three days after tightening, after which there is no impact. For these reasons, we view the evidence in favour of capital controls mitigating macroprudential concerns as being scant. ${ }^{26}$

To summarize, the event study reveals that post-event, the outcome variables on the whole do not show trends that one would expect if capital controls were effective. There is some evidence of a stemming of depreciation pressures on the currency post-easing, a stemming of appreciation pressures posttightening and reduced foreign currency borrowing post-tightening. However, we do not know if these trends reflect the impact of controls per se, or whether they would have materialized even if capital controls had not been changed when they were. To be confident that these results reflect a causal impact of capital controls, we need to take the next step, of using a control group of periods that were similar to the pre-event periods but where the treatment (CCA) was not applied. The next section presents the results of this analysis.

\footnotetext{
${ }^{26}$ As done for the motivations section, we did a robustness check with pre- and postglobal financial crisis periods for the easings. The results for the 2006-08 and 2009-13 periods are similar to those for the entire sample. In some cases, the evidence of ineffectiveness is stronger, as the pre-CCA trends in exchange rate variables are not abated but continue after the CCA. In the January 2004-May 2008 pre-crisis period, there are some differences, but these do not change the overall conclusion of ineffectiveness. The results are similar for exchange rate variables. Foreign borrowing and gross inflows initially increase post-easing, but these increases are quickly reversed. Bank credit growth rises post-easing in line with the expected impact, whereas stock prices show no significant trends.
} 


\begin{tabular}{|c|c|c|}
\hline Variable & Tron & \\
\hline Exchange rate objective & Easing & Tightening \\
\hline INR/USD returns & Halt depreciation & Halt appreciation \\
\hline Frankel-Wei residuals & Halt depreciation & Halt appreciation \\
\hline Exchange market pressure & Continued depreciation & Continued appreciation \\
\hline REER & Halt depreciation* & Halt appreciation* \\
\hline Macroprudential objective & Easing & Tightening \\
\hline Foreign borrowing (ECB) & No trend (no impact) & Decline \\
\hline Bank credit growth & Continued decline & Increase \\
\hline Gross inflows & No trend (no impact) & Continued increase \\
\hline Stock prices & No trend (no impact) & No trend (no impact) \\
\hline \multicolumn{3}{|c|}{$\begin{array}{l}\text { Notes: The table summarizes the statistically significant trends }(95 \%) \text { over seven } \\
\text { days for INR/USD returns, Frankel-Wei residuals and stock prices, three months for } \\
\text { REER and the exchange market pressure index, and six months/two quarters for } \\
\text { the other variables. * For REER, the results can be interpreted as halting deprecia- } \\
\text { tion/appreciation only if the pre-event horizon is two months. }\end{array}$} \\
\hline
\end{tabular}

Figure $11 \mathrm{INR} /$ USD fluctuations after the dates of CCAs

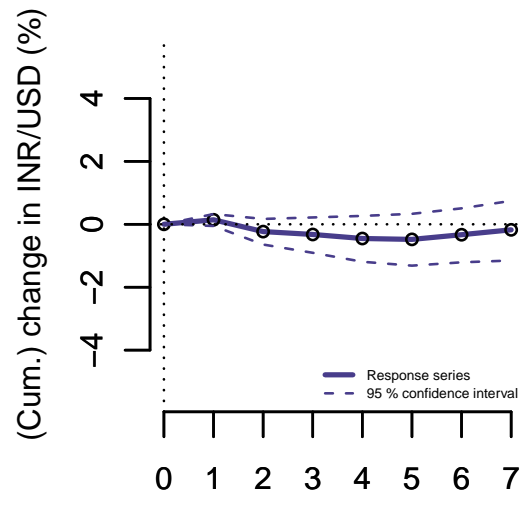

Event time (days)

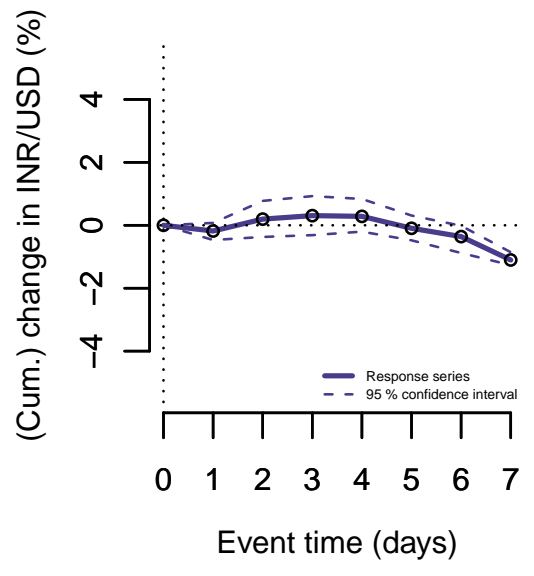

(b) 8 tightening events 
Figure 12 REER fluctuations after the dates of CCAs

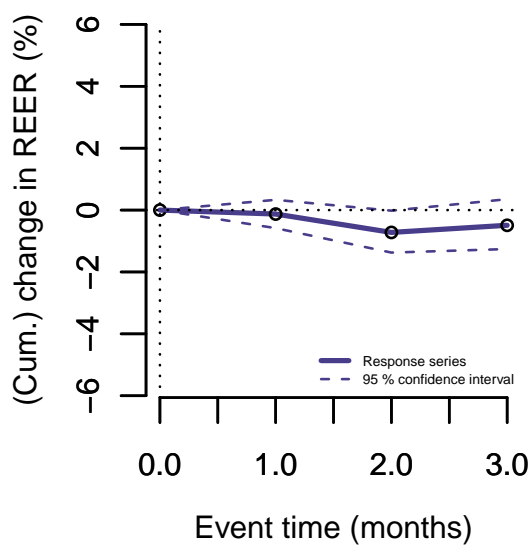

(a) 68 easing events

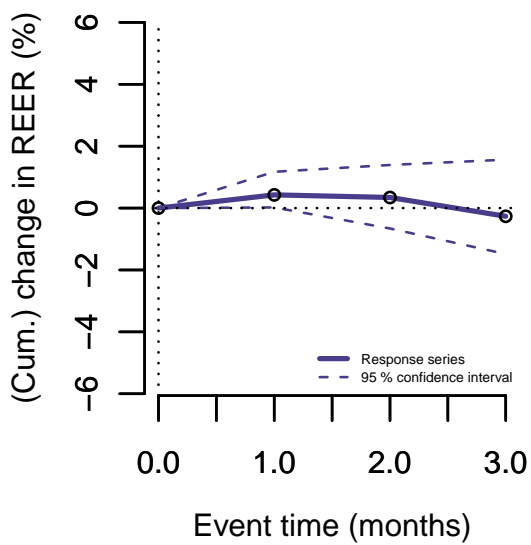

(b) 8 tightening events

Figure $13 \mathrm{FW}$ residual fluctuations after the dates of CCAs

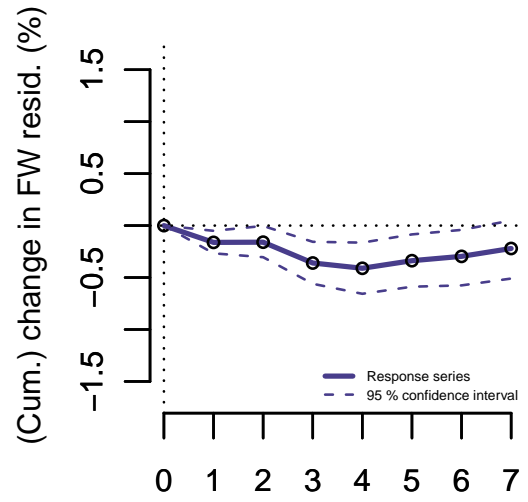

Event time (days)

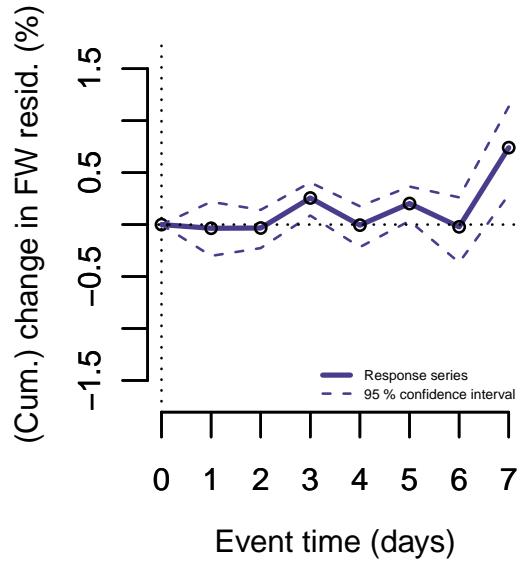
(b) 8 tightening events
(a) 68 easing events 
$\overline{\text { Figure } 14 \text { Movements in exchange market pressure after the dates of CCAs }}$

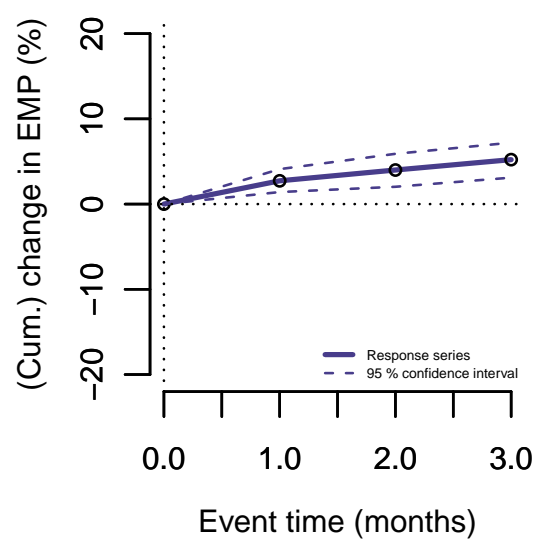

(a) 68 easing events

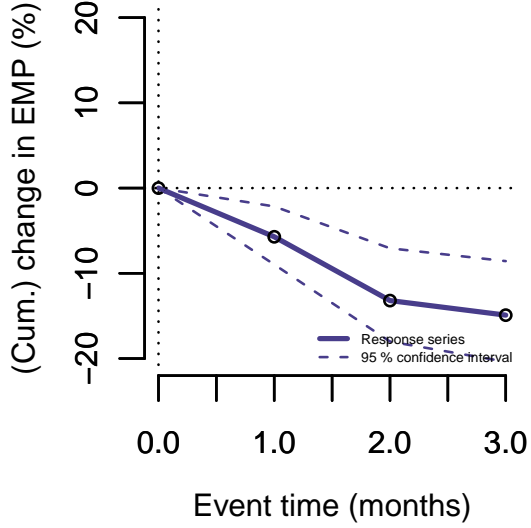

(b) 8 tightening events

Figure 15 Fluctuations in foreign borrowings after the dates of CCAs

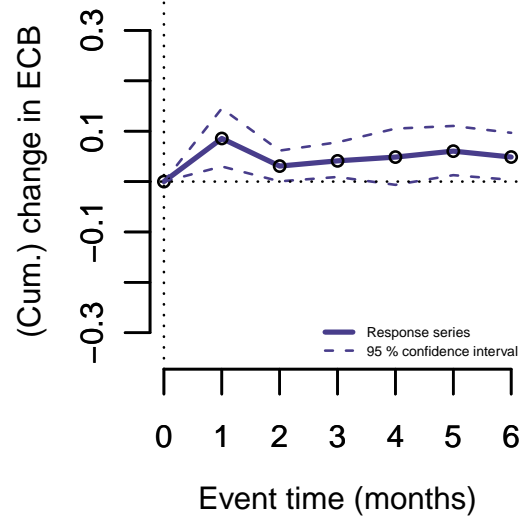

(a) 68 easing events

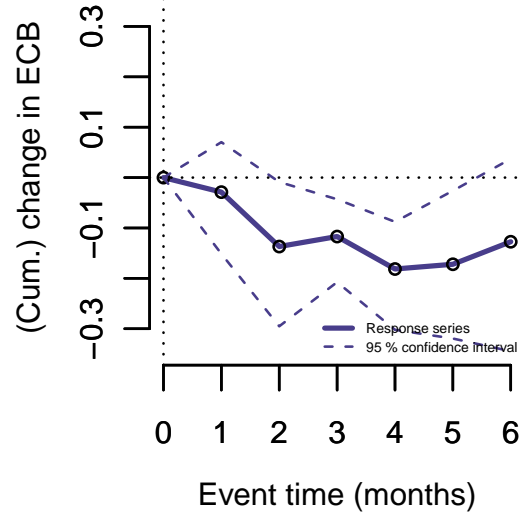

(b) 8 tightening events 
Figure 16 Fluctuations in overall capital flows after the dates of CCAs

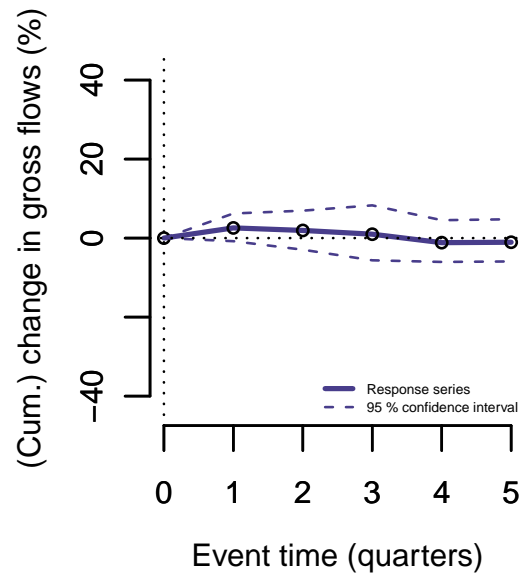

(a) 68 easing events

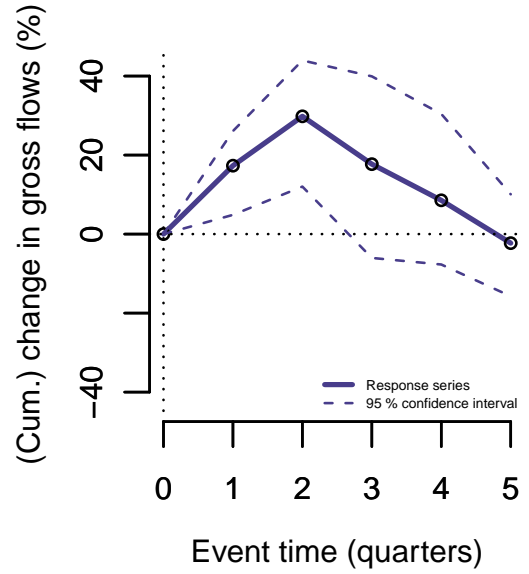

(b) 8 tightening events

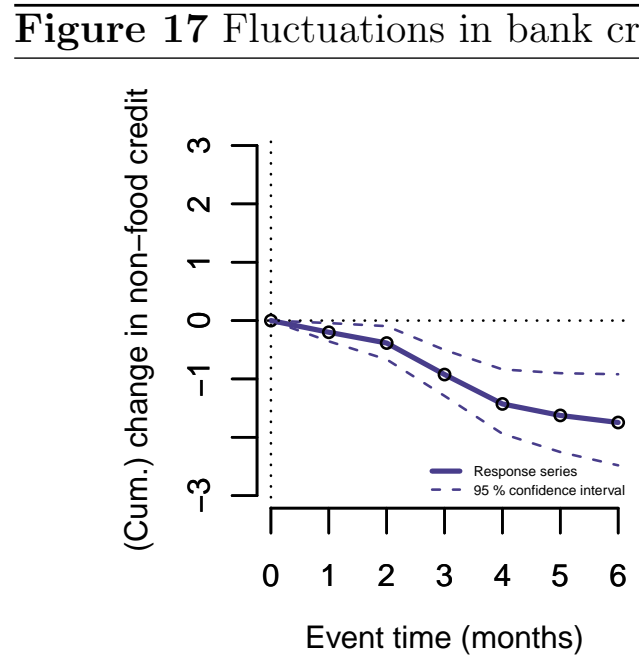

(a) 68 easing events

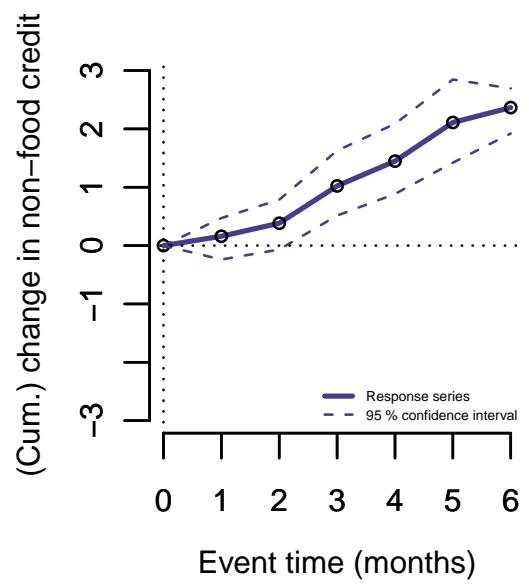

(b) 8 tightening events 
Figure 18 Fluctuations in stock prices after the dates of CCAs

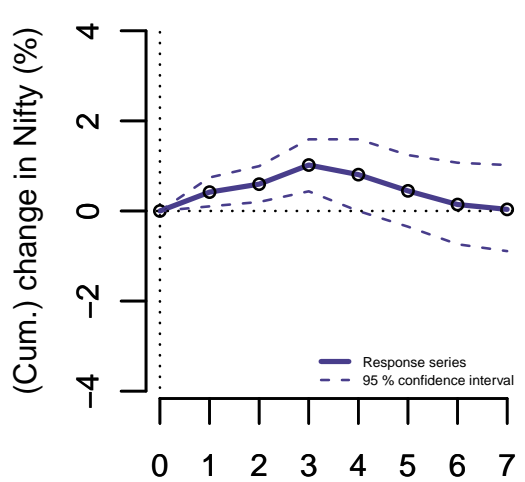

Event time (days)

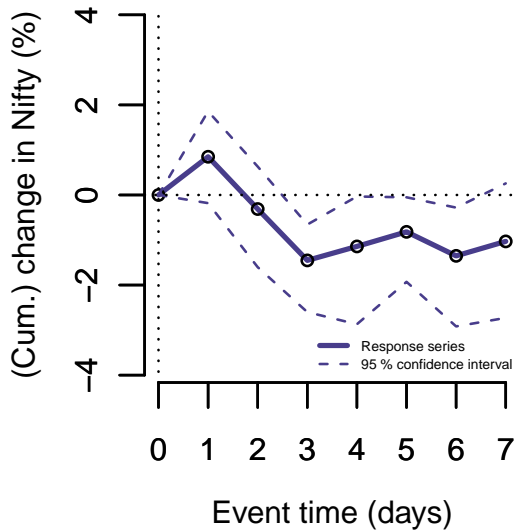

(b) 8 tightening events

(a) 68 easing events

\subsection{Causal analysis using propensity score matching}

The results of section 6 show that the RBI utilizes a certain selectivity process that determines when a CCA is employed. The time periods prior to the week of a CCA have certain characteristics. We use propensity score matching to identify similar time periods, when no CCA was employed. This gives a control time period (see Appendix D). The explanatory variables used in the logit model are the same as those in model 1 in Table 6: exchange rate changes, credit growth, money supply growth and returns on Nifty. ${ }^{27}$

While only a small set of explanatory variables were used in the logit model, match balance is achieved for a broad set of time-series variables, as shown in Table 9. In this table, the null of equality of distributions is always rejected before matching and is broadly not rejected after matching. This suggests that we have succeeded in finding a set of 22 control weeks when macroeconomic conditions were much like the 22 treatment weeks. Figure 19 shows that the cumulative density of the propensity scores is highly unequal before matching, but after the matching, the two distributions are alike, indicating that there is match balance.

Using this matched sample of 22 weeks with a CCA and 22 weeks with no CCA, we conduct an event study about returns on the INR/USD exchange rate. This result is shown in Figure 20. The difference in returns between

${ }^{27}$ Our results are robust to using model 2 in Table 6. 
each pair is averaged and cumulated. We know from Figure 3 that rupee depreciation took place in the weeks prior to a CCA. Since the control weeks are similar, rupee depreciation also took place in the weeks prior to the similar date with no CCA. Hence, we see no significant difference prior to the event date in the event study. Turning to the period after the event date, we see no statistically significant impact, since there is no difference between the treatment week and the control week. ${ }^{28}$

Figure 19 Cumulative density function of the propensity scores before and after matching
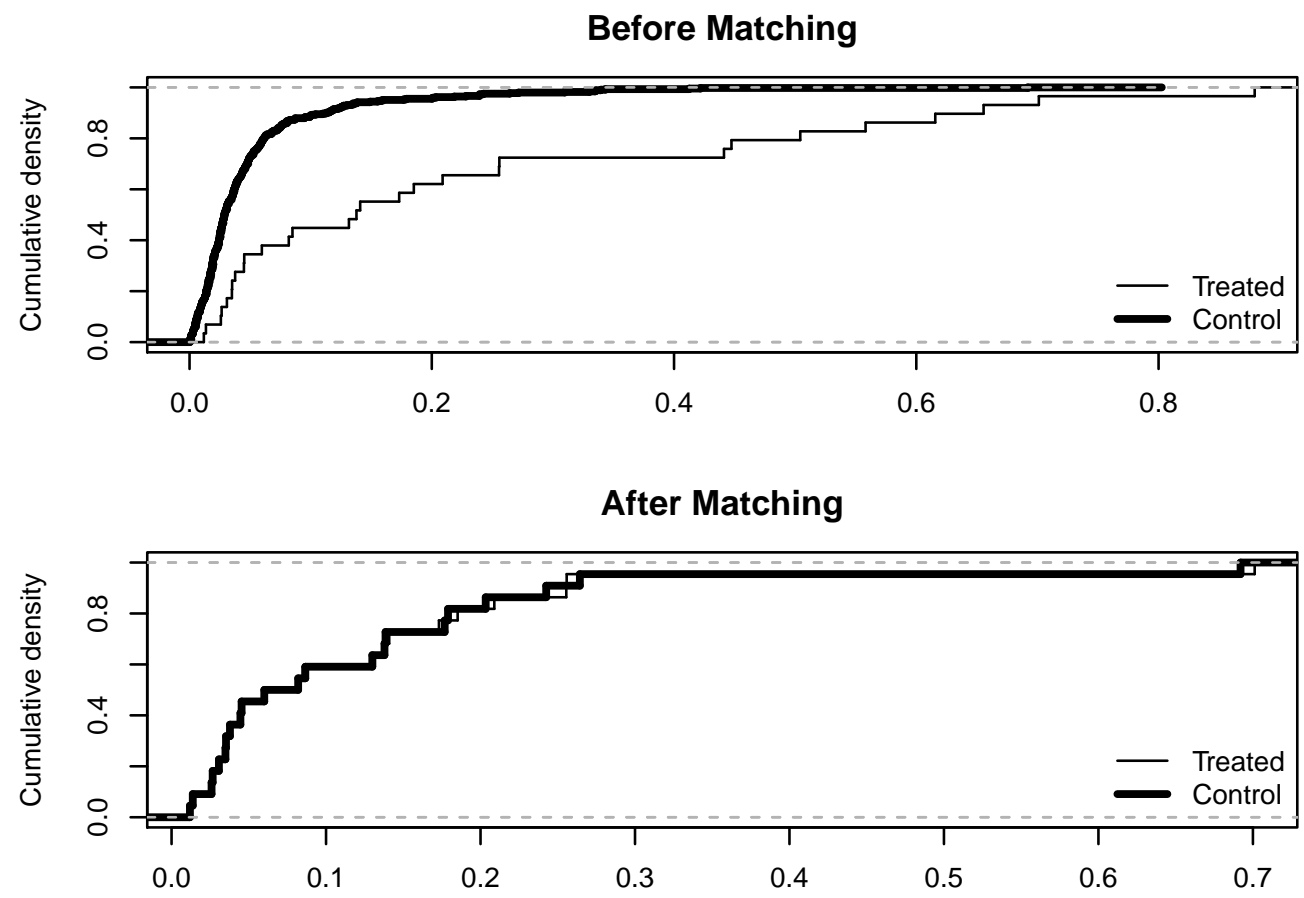

Table 10 applies such causal analysis to multiple outcome measures. Whether we look at the residuals of the Frankel-Wei regression, the stock market index or credit growth, there is no statistically significant impact.

\footnotetext{
${ }^{28}$ Our results on effectiveness are robust to using the genetic matching algorithm, as described in the methodology section.
} 
Table 9 Kolmogorov-Smirnov test for equality of distributions

The table shows the Kolmogorov-Smirnov test result for a broad set of variables for the treated and control group before and after matching. The values in parentheses are $p$ values. FII refers to foreign institutional investors.

\begin{tabular}{|c|c|c|}
\hline & Before Matching & After Matching \\
\hline Propensity score & $\begin{array}{l}0.49 \\
(0)\end{array}$ & $\begin{array}{l}0.09 \\
(1)\end{array}$ \\
\hline INR/USD returns $_{t-1}$ & $\begin{array}{l}0.33 \\
(0.01)\end{array}$ & $\begin{array}{l}0.23 \\
(0.63)\end{array}$ \\
\hline Bank credit growth ${ }_{t-1}$ & $\begin{array}{l}0.11 \\
(0.88)\end{array}$ & $\begin{array}{l}0.09 \\
(1)\end{array}$ \\
\hline M3 growth $_{t-1}$ & $\begin{array}{l}0.11 \\
(0.87)\end{array}$ & $\begin{array}{l}0.23 \\
(0.62)\end{array}$ \\
\hline Nifty returns $_{t-1}$ & $\begin{array}{l}0.28 \\
(0.03)\end{array}$ & $\begin{array}{l}0.41 \\
(0.05)\end{array}$ \\
\hline FW predicted $_{t-1}$ & $\begin{array}{l}0.09 \\
(0.97)\end{array}$ & $\begin{array}{l}0.14 \\
(0.99)\end{array}$ \\
\hline $\mathrm{FW}$ residuals $_{t-1}$ & $\begin{array}{l}0.33 \\
(0.01)\end{array}$ & $\begin{array}{l}0.23 \\
(0.63)\end{array}$ \\
\hline Net FII inflows ${ }_{t-1}$ & $\begin{array}{l}0.35 \\
(0.01)\end{array}$ & $\begin{array}{l}0.33 \\
(0.22)\end{array}$ \\
\hline INR/USD returns $_{t-2}$ & $\begin{array}{l}0.32 \\
(0.01)\end{array}$ & $\begin{array}{l}0.32 \\
(0.22)\end{array}$ \\
\hline Bank credit growth $_{t-2}$ & $\begin{array}{l}0.05 \\
(1)\end{array}$ & $\begin{array}{l}0.14 \\
(0.99)\end{array}$ \\
\hline M3 growth $_{t-2}$ & $\begin{array}{l}0.13 \\
(0.7)\end{array}$ & $\begin{array}{l}0.18 \\
(0.86)\end{array}$ \\
\hline Nifty returns $_{t-2}$ & $\begin{array}{l}0.22 \\
(0.13)\end{array}$ & $\begin{array}{l}0.18 \\
(0.87)\end{array}$ \\
\hline FW predicted $_{t-2}$ & $\begin{array}{l}0.24 \\
(0.11)\end{array}$ & $\begin{array}{l}0.36 \\
(0.11)\end{array}$ \\
\hline FW residuals $t_{t-2}$ & $\begin{array}{l}0.3 \\
(0.02)\end{array}$ & $\begin{array}{l}0.18 \\
(0.87)\end{array}$ \\
\hline Net FII inflows $t_{t-2}$ & $\begin{array}{l}0.16 \\
(0.68)\end{array}$ & $\begin{array}{l}0.54 \\
(0.01)\end{array}$ \\
\hline INR/USD returns $_{t-3}$ & $\begin{array}{l}0.45 \\
(0)\end{array}$ & $\begin{array}{l}0.23 \\
(0.63)\end{array}$ \\
\hline Bank credit growth $_{t-3}$ & $\begin{array}{l}0.11 \\
(0.9)\end{array}$ & $\begin{array}{l}0.14 \\
(0.99)\end{array}$ \\
\hline M3 growth $_{t-3}$ & $\begin{array}{l}0.07 \\
(1)\end{array}$ & $\begin{array}{l}0.09 \\
(1)\end{array}$ \\
\hline Nifty returns $_{t-3}$ & $\begin{array}{l}0.29 \\
(0.02)\end{array}$ & $\begin{array}{l}0.23 \\
(0.63)\end{array}$ \\
\hline FW predicted $t-3$ & $\begin{array}{l}0.17 \\
(0.5)\end{array}$ & $\begin{array}{l}0.27 \\
(0.36)\end{array}$ \\
\hline FW residuals $t_{t-3}$ & $\begin{array}{l}0.34 \\
(0.01)\end{array}$ & $\begin{array}{l}0.17 \\
(0.84)\end{array}$ \\
\hline Net FII inflows $t_{t-3}$ & $\begin{array}{l}0.12 \\
(0.92)\end{array}$ & $\begin{array}{l}0.32 \\
(0.24)\end{array}$ \\
\hline
\end{tabular}


Figure 20 Causal impact of CCAs upon the INR/USD returns

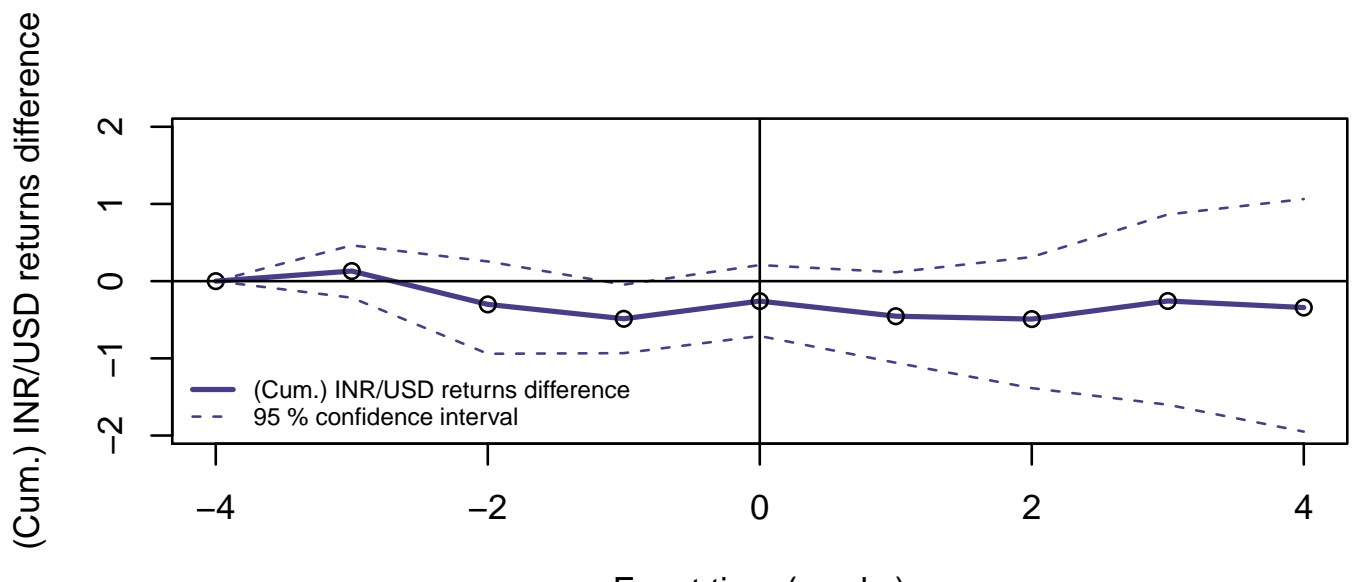

Event time (weeks)

Table 10 Causal analysis of various outcome variables

For 22 matched pairs, the table shows the test of equality of means between the treated and control weeks at a horizon of $1,2,3$ and 4 weeks after the event. ${ }^{* *}$ indicates significance at the $5 \%$ level and * indicates significance at the $10 \%$ level.

Credit growth

\begin{tabular}{|c|c|c|}
\hline & OLS & Robust \\
\hline 1 & $-0.26(0.52)$ & $-0.23(0.53)$ \\
\hline 2 & $-0.16(0.52)$ & $-0.13(0.55)$ \\
\hline 3 & $-0.21(0.63)$ & $-0.28(0.64)$ \\
\hline & $-0.17(0.63)$ & $-0.19(0.65)$ \\
\hline
\end{tabular}

Stock prices

\begin{tabular}{|c|c|c|}
\hline & OLS & Robust \\
\hline 1 & $0.08(2.64)$ & $0.29(2.8)$ \\
\hline 2 & $-1.36(2.85)$ & $-0.63(2.88)$ \\
\hline 3 & $-2.32(3.31)$ & $-1.54(3.22)$ \\
\hline 4 & $-2.44(3.4)$ & $-1.65(3.21)$ \\
\hline
\end{tabular}

FW residuals

\begin{tabular}{lll}
\hline & OLS & Robust \\
\hline 1 & $-0.2(0.45)$ & $-0.12(0.43)$ \\
2 & $-0.2(0.56)$ & $0.01(0.52)$ \\
3 & $-0.17(0.73)$ & $0.17(0.82)$ \\
4 & $-0.4(0.87)$ & $0.08(1.09)$ \\
\hline
\end{tabular}

Net foreign institutional investor inflows

\begin{tabular}{lll}
\hline & OLS & Robust \\
\hline 1 & $0.14(0.1)$ & $0.14(0.1)$ \\
2 & $0.18(0.11)$ & $0.18(0.11)$ \\
3 & $0.16(0.13)$ & $0.15(0.13)$ \\
4 & $0.14(0.14)$ & $0.13(0.15)$ \\
\hline
\end{tabular}

Square of INR/USD returns

\begin{tabular}{|c|c|c|}
\hline & OLS & Robust \\
\hline 1 & $1.68(0.96)^{*}$ & $1.82(1.05)^{*}$ \\
\hline 2 & $2.28(1.08) * *$ & $1.37(0.9)$ \\
\hline 3 & $3.25(1.35)$ ** & $1.71(1.44)$ \\
\hline 4 & $3.51(1.52) * *$ & $2.43(2.66)$ \\
\hline
\end{tabular}




\section{Summary and Conclusions}

There is renewed interest in reassessing the potential role for capital controls as a tool for macroeconomic or macroprudential policy. In well-structured financial regulatory regimes, regulations that restrict capital account transactions would ideally be precisely stated and backed by cost-benefit analysis.

Of particular importance are comprehensive administrative systems that cover all kinds of capital account transactions, since the evidence shows that the episodic use of capital controls in an otherwise open capital account has low effectiveness. Within the broad range of restrictions, there is particular interest in restricting foreign borrowing, given the potential implications for systemic risk.

Four important unanswered questions can be identified. First, what are capital controls? Second, when do policy-makers actually use capital controls? Third, what is the causal impact of various kinds of CCAs? Finally, do the benefits of capital controls outweigh their costs?

In this paper, we study one large country, India, which is a rare example of a comprehensive administrative system of capital controls. Such a comprehensive system is advocated in some of the recent proposals to resurrect capital controls. We focus on one class of restrictions - on foreign borrowing which could be important from the viewpoint of systemic risk.

Building on the recent work of Pasricha (2012) and Forbes et al. (2013), we analyze individual CCAs, rather than the low-frequency measures of capital account openness that have dominated the traditional literature. We improve upon existing work by undertaking a thorough legal analysis of every CCA, and arrive at a new data set of 76 CCAs. An avenue for future research is to build a similar standardized classification system for multiple countries that would allow similar cross-country studies of capital controls.

Our analysis yields two main results. First, the Indian authorities seem to employ CCAs primarily in response to exchange rate movements. In particular, they seem to respond to the country-specific component of exchange rate movements.

The second result is about the impact of these capital control actions. The treatment effect is analyzed in two ways: event study and propensity score matching. Both kinds of analysis show that the CCAs have no robust impact. This result is consistent with the recent literature on capital controls in India (Patnaik and Shah, 2012) and in other countries (Jinjarak et al., 2013). 
Our results are also consistent with the mainstream capital controls literature from the 1980s and 1990s. The Indian authorities seem to be utilizing CCAs to pursue exchange rate policy and not for systemic risk reduction, and their actions do not seem to be effective in influencing either the exchange rate or other outcomes. 


\section{References}

Aggarwal, N. and S. Thomas (2013). Market quality in the time of algorithmic trading. Technical Report December, IGIDR FRG.

Aizenman, J. and G. K. Pasricha (2013). Why do emerging markets liberalize capital outflow controls? fiscal versus net capital flow concerns. Journal of International Money and Finance 39(C), 28-64.

Anand, C., V. Bahure, V. Balasubramaniam, and A. Shah (2014). eventstudies: An $R$ package for researchers and users of event studies. NIPFP.

Angrist, J. and J. Hahn (2004). When to control for covariates? panel asymptotics for estimates of treatment effects. Review of Economics and Statistics 86(1), 58-72.

Angrist, J. and J.-S. Pischke (2008). Mostly Harmless Econometrics: An Empiricist's Companion. Princeton University Press.

Angrist, J. D. and G. M. Kuersteiner (2011). Causal effects of monetary shocks: semiparametric conditional independence tests with a multinomial propensity score. The Review of Economics and Statistics 93(3), 725-747.

Bank of England (2009). The role of macroprudential policy. Bank of England Discussion Paper 19 November 2009.

BIS, FSB, and IMF (2011, February). Macroprudential policy tools and frameworks: Update to G20 finance ministers and central bank governors. Technical report, Bank for International Settlements.

Blanchard, O. (2013). Monetary policy will never be the same. iMFDirect 19 November.

Blundell-Wignall, A. and C. Roulet (2013). Capital controls on inflows, the global financial crisis and economic growth: Evidence for emerging economies. OECD Journal: Financial Market Trends 2.

Caliendo, M. and S. Kopeinig (2005). Some practical guidance for the implementation of propensity score matching. Discussion Paper 1588, Institute for the Study of Labor (IZA).

Carvalho, B. S. d. M. and M. G. P. Garcia (2008). Ineffective controls on capital inflows under sophisticated financial markets: Brazil in the nineties. In S. Edwards and M. G. P. Garcia (Eds.), Financial Markets Volatility 
and Performance in Emerging Markets, pp. 29-96. University of Chicago Press.

Chinn, M. and H. Ito (2008). A new measure of financial openness. Journal of Comparative Policy Analysis 10(3), 309-322.

Davison, A. C., D. V. Hinkley, and E. Schechtman (1986). Efficient bootstrap simulation. Biometrika 73(3), 555-566.

Edwards, S. (1999). How effective are capital controls? NBER Working Papers 7413, National Bureau of Economic Research, Inc.

Edwards, S. and J. D. Ostry (1992, January). Terms of trade disturbances, real exchange rates, and welfare: The role of capital controls and labor market distortions. Oxford Economic Papers 44(1), 20-34.

Eichengreen, B., R. Hausmann, and U. Panizza (2007). Currency mismatches, debt intolerance, and the original sin: Why they are not the same and why it matters. In Capital Controls and Capital Flows in Emerging Economies: Policies, Practices and Consequences, NBER Chapters, pp. 121-170. National Bureau of Economic Research, Inc.

Felman, J. and I. Patnaik (2013). Did QE Unleash a Monetary Tsunami? An Exchange Market Pressure Approach. Technical report, National Institute of Public Finance and Policy.

Forbes, K., M. Fratzscher, and R. Straub (2013). Capital controls and macroprudential measures: What are they good for? Discussion Papers of DIW Berlin 1343, DIW Berlin, German Institute for Economic Research.

Forbes, K. J. (2004). Capital controls: Mud in the wheels of market discipline. Working papers 4454-03, Massachusetts Institute of Technology (MIT), Sloan School of Management.

Forbes, K. J. (2005). The microeconomic evidence on capital controls: No free lunch. NBER Working Papers 11372, National Bureau of Economic Research, Inc.

Frankel, J. and S.-J. Wei (1994). Yen bloc or dollar bloc? Exchange rate policies of the East Asian countries. In T. Ito and A. Krueger (Eds.), Macroeconomic Linkage: Savings, Exchange Rates and Capital Flows. University of Chicago Press.

Fratzscher, M. (2012). Capital controls and foreign exchange policy. Working Paper 1415, European Central Bank. 
Goldstein, M. and P. Turner (2004). Controlling Currency Mismatches in Emerging Markets. Number 373 in Peterson Institute Press: All Books. Peterson Institute for International Economics.

Haldane, A. G. and S. G. Hall (1991). Sterling's relationship with the dollar and the deutschemark: 1976-89. The Economic Journal 101, 436-443.

Hutchison, M. M., G. K. Pasricha, and N. Singh (2012). Effectiveness of capital controls in India: Evidence from the offshore NDF market. IMF Economic Review 60(3), 395-438.

IMF (2012). The liberalization and management of capital flows - an institutional view. Policy paper, International Monetary Fund.

Jadhav, N. (2003). Capital account liberalisation: the indian experience. Reserve Bank of India (Mumbai).

Jinjarak, Y., I. Noy, and H. Zheng (2013). Capital controls in brazilstemming a tide with a signal? Journal of Banking 85 Finance 37(8), 2938-2952.

Klein, M. W. (2012). Capital controls: Gates versus walls. Brookings Papers on Economic Activity 45(2 (Fall)), 317-367.

Kothari, S. and J. Warner (2007). Econometrics of event studies. In B. E. Eckbo (Ed.), Handbook of Corporate Finance, Volume 1, Chapter 1, pp. 29-96. Elsevier.

Magud, N. E., C. M. Reinhart, and K. S. Rogoff (2011). Capital Controls: Myth and Reality - A Portfolio Balance Approach. Working Paper 16805, National Bureau of Economics Research.

Moura, M. L., F. R. Pereira, and G. de Moraes Attuy (2013). Currency wars in action: How foreign exchange interventions work in an emerging economy. Technical Report March, Insper.

Nier, E., J. Osiski, J. Chen, H. Kang, Y. Kim, I. Krznar, R. D. Mooji, M. Keen, L. Ratnoski, and P. Kongsamut (2013). Key aspects of macroprudential policy. Technical report, IMF Background Paper.

OECD (2012). Recommendation of the council on regulatory policy and governance. Report, Organisation for Economic Co-operation and Development. 
Ostry, J., A. R. Ghosh, K. Habermeier, M. Chamon, M. S. Qureshi, and D. B. Reinhardt (2010). Capital inflows: The role of controls. Staff Position Note SPN/10/04, International Monetary Fund.

Ostry, J. D., A. R. Ghosh, M. Chamon, and M. S. Qureshi (2012). Tools for managing financial-stability risks from capital inflows. Journal of International Economics 88(2), 407 - 421.

Pasricha, G. K. (2012). Recent trends in measures to manage capital flows in emerging economies. The North American Journal of Economics and Finance 23(3), 286-309.

Patnaik, I. and A. Shah (2012). Did the Indian capital controls work as a tool of macroeconomic policy. IMF Economic Review 60(3), 439-464.

Patnaik, I., A. Shah, and N. Singh (2013, September). Foreign investors under stress: Evidence from india. International Finance 16(2), 213-244.

Pradhan, M., R. Balakrishnan, R. Baqir, G. Heenan, S. Nowak, C. Oner, and S. Panth (2011). Policy responses to capital flows in emerging markets. Technical report, IMF Staff Discussion Note.

Schindler, M. (2009). Measuring financial integration: A new data set. IMF Staff Papers 56(1), 222-238.

Sekhon, J. S. (2011). Multivariate and Propensity Score Matching Software with Automated Balance Optimization: The Matching package for R. Journal of Statistical Software, American Statistical Association 42(7).

Sinha, U. K. (2010). Working group on foreign investment. Committee report, Department of Economic Affairs, Ministry of Finance, Government of India. 


\section{A Construction of the CCA database: Two examples}

In this appendix, we present two examples of our methodology for translating CCAs into a consistent database for evaluating the effectiveness of controls.

1. On 21 May 2007, an RBI circular (http://rbi.org. in/scripts/NotificationUser. aspx? $I d=3544 \&$ Mode $=0$ ) reduced the spread on all-in-cost ceilings to 150 basis points for maturities of three to five years and to 250 basis points for maturities of more than five years. The reduced spread was also announced for borrowers under the approval route. End-use requirements governing external borrowings were tightened: proceeds from external commercial borrowing (ECB) could no longer be used for investing in real estate, including integrated townships.

From this circular we get three tightening events:

(a) The all-in-cost ceilings were reduced for eligible borrowers under the automatic route.

(b) The all-in-cost ceilings were reduced for eligible borrowers under the approval route.

(c) The end-use restrictions were tightened.

For this date we get three records in the CCA database, all of which are tightening. Pasricha (2012) classifies these three events introduced on a single day as two tightening events: it groups the two price-based measures (cost-ceiling changes) as one event and categorizes the end-use restrictions as a quantitative event. These changes may have differential impact on the different types of borrowers (firms under approval and automatic routes). Hence, for the purpose of assessing the impact of controls, they merit independent counting as three tightening events.

2. On 29 May 2008, an RBI circular (http://rbi.org.in/scripts/NotificationUser. aspx $? \mathrm{Id}=4200 \&$ Mode $=0$ ) eased capital controls in three directions:

(a) The restrictions on all-in-cost ceilings were eased to 200 basis points from 150 basis points for three- to five-year maturities and from 250 to 350 basis points over six-month LIBOR for above-five-year maturities.

(b) Borrowers that were infrastructure firms were permitted to borrow through ECB with a limit of USD 100 million, for the purpose of rupee expenditure, for permissible end uses, under the approval route.

(c) For other borrowers, the existing limit of USD 20 million for rupee expenditure for permissible end uses under the approval route was enhanced to USD 50 million. 
For this date we get three records in the CCA database, and all three are easing. This circular cannot be read independently. The nature of change introduced in this circular is different from the previous example. In this circular, several of the previous tightening events were reversed. This requires tracking all the previous circulars to get an idea of the sequential liberalization of tightening measures.

From this circular, we get three easing events related to the following aspects of ECB regulation:

(a) Easing of all-in-cost ceilings.

(b) Easing of restrictions on eligible borrowers under the approval route.

(c) Easing of restrictions on permissible amounts.

Pasricha (2012) counts the cost ceilings as one event and groups the other two quantitative changes as one event. In our classification system, these are viewed as three distinct easing events, since the nature of changes introduced through this circular are different and may have differential impact for different borrowers.

In this way, we do a careful reading of each of the 97 circulars and track changes related to all aspects of ECB regulation. This approach sheds light on the minutest details of changes in capital controls. For example, while Forbes et al. (2013) identifies five events directed toward easing, our approach (that focuses on controls on one category of international capital transactions, i.e., external borrowing) is able to identify 14 easing events in the period 2009-11. The number is likely to go up if we extend this approach to tracking capital controls on all categories of international transactions. 


\section{B Was currency volatility the driver?}

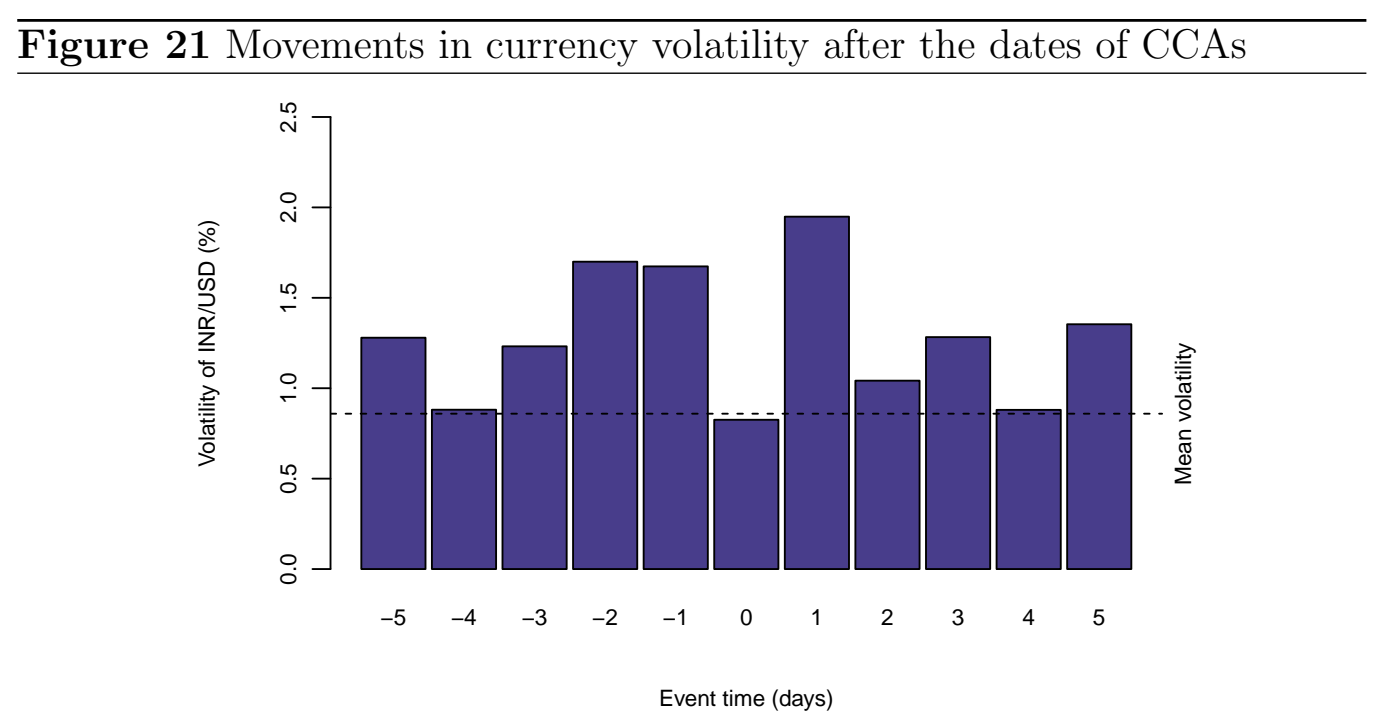

(a) 68 easing events

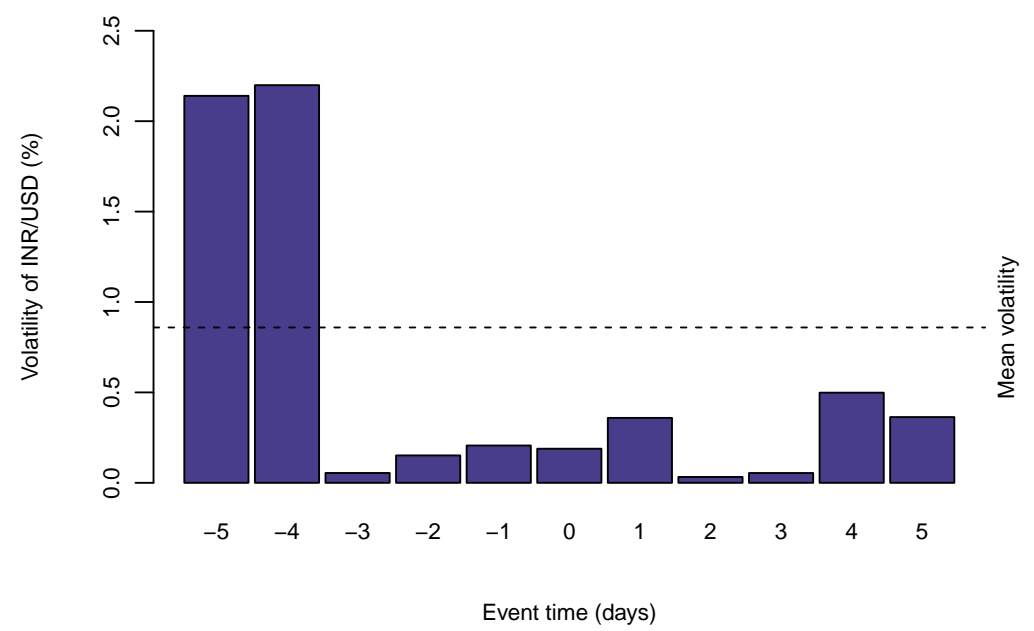

(b) 8 tightening events 
Figure 22 Movements in FW residual volatility after the dates of CCAs

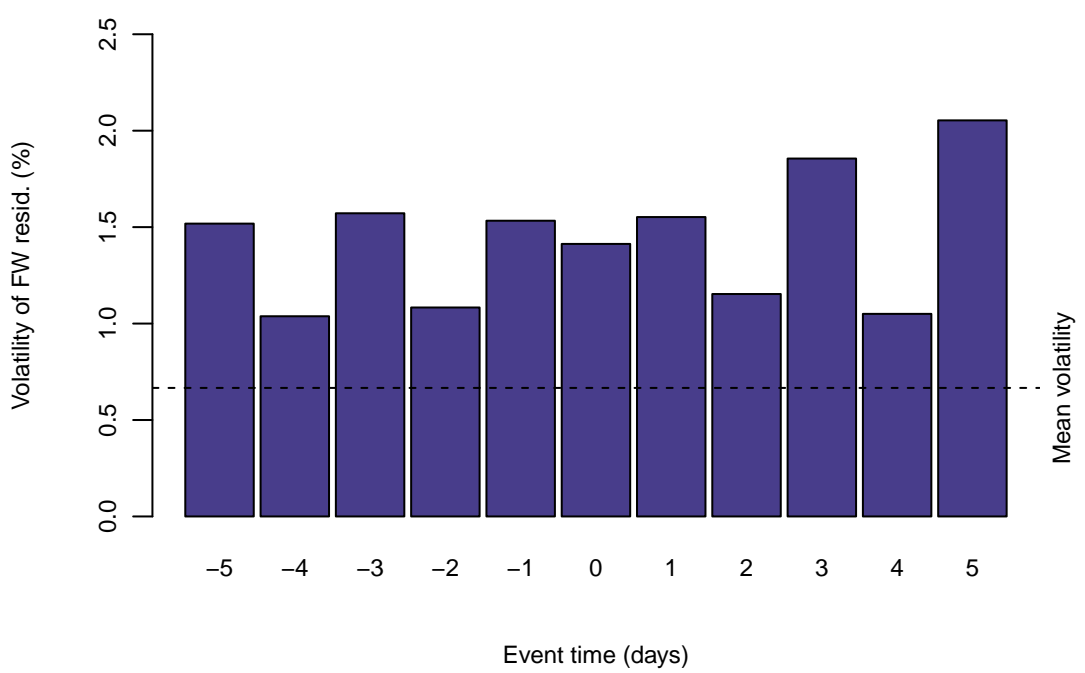

(a) 68 easing events

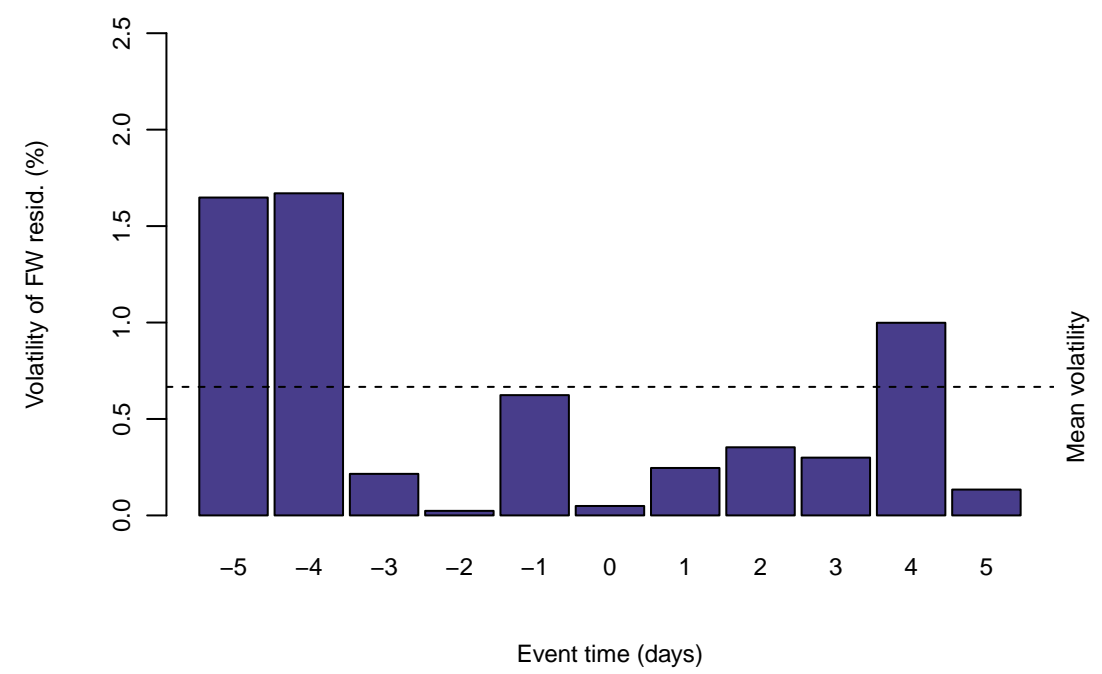

(b) 8 tightening events 


\section{Data sources}

\begin{tabular}{ll}
\hline Table 11 Data sources & \\
\hline \hline Variables & Sources \\
\hline Rupee-U.S. dollar exchange rate & Reserve Bank of India \\
Frankel-Wei residuals & India-specific component of fluctuations in \\
& INR/USD exchange rate based on \\
& Frankel and Wei (1994) methodology \\
Exchange market pressure & Felman and Patnaik (2013) \\
& measure expressed in terms of \\
& per cent change in exchange \\
& rate at a monthly frequency \\
Real effective exchange rate & Bank for International Settlements \\
Foreign borrowing & Reserve Bank of India \\
Private bank credit growth & Reserve Bank of India \\
Stock price returns & National Stock Exchange \\
Gross capital flows & Reserve Bank of India \\
Money supply (M3) & Reserve Bank of India \\
\hline
\end{tabular}




\section{Matching for dates of CCAs}

We show the list of weeks with CCAs and the matched week with no CCA that was identified using propensity score matching.

\begin{tabular}{ll}
\hline Treated & Control \\
\hline $2004-02-06$ & $2004-10-08$ \\
$2005-04-29$ & $2005-06-03$ \\
$2005-08-05$ & $2003-01-10$ \\
$2006-12-08$ & $2005-06-24$ \\
$2008-10-31$ & $2009-03-13$ \\
$2010-01-29$ & $2003-07-04$ \\
$2010-03-05$ & $2009-01-30$ \\
$2010-05-14$ & $2005-11-25$ \\
$2010-07-23$ & $2009-03-20$ \\
$2010-08-13$ & $2006-07-07$ \\
$2011-12-23$ & $2004-05-28$ \\
$2012-01-06$ & $2009-07-03$ \\
$2012-03-02$ & $2011-08-19$ \\
$2012-04-20$ & $2010-11-19$ \\
$2012-04-27$ & $2004-05-07$ \\
$2012-09-14$ & $2007-06-08$ \\
$2012-11-09$ & $2010-12-10$ \\
$2012-11-30$ & $2009-09-04$ \\
$2012-12-14$ & $2006-04-14$ \\
$2012-12-21$ & $2008-03-28$ \\
$2013-01-11$ & $2011-05-27$ \\
$2013-07-12$ & $2012-08-03$ \\
\hline &
\end{tabular}

